Harmandar, D. ve Arıkan, A. (2020). Erken okuryazarlık becerilerine yönelik dil destek çalışmalarında ailelerin tercihleri. Ana Dili Eğitimi Dergisi, 8(4), 1183-1203.

\begin{tabular}{c}
$\begin{array}{c}\text { Ana Dili Eğitimi Dergisi } \\
\text { Journal of Mother Tongue Education } \\
\text { www.anadiliegitimi.com }\end{array}$ \\
$\begin{array}{c}\text { Geliş/Received: } 28.07 .2020 \text { Kabul/Accepted:09.09.2020 } \\
\text { Araştırma Makalesi / Research Paper }\end{array}$ \\
\hline
\end{tabular}

\title{
Erken Okuryazarlık Becerilerine Yönelik Dil Destek Çalışmalarında Ailelerin Tercihleri* ${ }^{* *}$
}

\author{
Dilara HARMANDAR ${ }^{* * *}$ \\ ArzU ARIKAN****
}

Öz

Okulöncesi dönemde kazanılan erken okuryazarlık becerileri çocukların gelecek başarıları ve gelişimlerinde kritik bir rol oynamaktadır. Bu becerilerin desteklenmesi için ailelerin de çocuklara zengin uyaranlar sunmaları ve eğitsel çalışmalara katılmaları gerekmektedir. Ailelerin erken okuryazarlık becerileri konusundaki çalışmalara katıımını artırmak içinse planlama sürecinde ailelerin görüşlerine başvurmak önemlidir. Bu araştırmanın amacı da ailelerin okulöncesi dönemde erken okuryazarlık becerileri odaklı dil destek çalışmaları konusundaki tercihlerini betimlemektir. Tarama deseninde yürütülen araştırmanın örneklemini resmi ve özel okullarda öğrenim gören 5-6 yaşlarındaki 640 çocuğun ebeveyni oluşturmuştur. Veri analizinde betimleyici istatistiklere ve nonparametrik testlere başvurulmuştur. Bulgular; ailelerin çocukları ile etkileşimlerinde en çok eğitici ve ilgi çekici olma konusunda bilgi istediğini ve bilgilendirme aracı olarak yazılı materyalleri tercih ettiğini göstermektedir. Çalışmalara katııımda aileleri en fazla sınırlayan faktör ise zaman/enerji yokluğudur. Ailelerin tercihlerinde sosyoekonomik katman ve diğer demografik değişkenlere göre de anlamlı farklara ulaşıımıştır.

Anahtar Kelimeler: Okulöncesi eğitim, erken okuryazarlık gelişimi, aile okuryazarlığı, ebeveyn katılımı.

\section{Family Preferences for Language Support Programs about Early Literacy}

\begin{abstract}
Early literacy skills acquired in preschool period have a critical role in children's future success and development. To support these skills, families should also offer rich stimuli at home and participate in language support programs. For increasing families' participation and learning in these programs, consulting with families during the planning process is crucial. This study aims to describe families' preferences for language support activities focused on developing early literacy skills. The sampling in this survey research included the 640 parents of 5-6 years old children attending public and private schools in Turkey. Data analysis employed descriptive statistics, nonparametric tests, and cluster analysis. The results show that families mostly want information about being educational and engaging in their interactions and prefer written materials to receive information. The most common barrier for families is lack of time/energy. There were significant differences in the preferences of families based on socioeconomic status and other demographic variables.
\end{abstract}

Keywords: Preschool education, early literacy development, family literacy, parent involvement.

\footnotetext{
${ }^{*}$ Bu çalışma ilk yazarın yüksek lisans tezinin bir bölümünden üretilmiş olup çalışmanın erken bir örneği, 2019 yılında $\mathrm{VI}^{\text {th }}$ International Eurasian Educational Research Congress etkinliğinde sözlü bildiri olarak sunulmuştur. ${ }^{* *}$ Araştırmanın etik kurulu izni: Anadolu Üniversitesi Etik Kurulu, 15/05/2018, 54380210-050.99

*** Öğr. Gör., Pamukkale Üniversitesi, Kale Meslek Yüksekokulu, Çocuk Gelişimi Bölümü, Denizli, dharmandar@pau.edu.tr, ORCID: 0000-0002-0865-5090

**** Dr. Öğr. Üyesi, Anadolu Üniversitesi, Eğitim Fakültesi, Temel Eğitim Bölümü, Eskişehir, arzuarikan@anadolu.edu.tr, ORCID: 0000-0002-4602-8901
} 


\section{Giriş}

Okulöncesi eğitim programının temel amaçları arasında çocukları ilkokula hazırlamak ve Türkçeyi doğru ve güzel konuşmalarını sağlamak yer almaktadır (MEB, 2013). İlkokula hazırlık ve ifade edici dil becerilerini vurgulayan bu temel amaç aslında erken okuryazarlık kavramı ile doğrudan ilişkilidir. Bu amaç doğrultusunda okul öncesi eğitim programında da erken okuryazarlık becerilerine yönelik kazanım ve göstergelerin önemli bir yeri vardır. Erken okuryazarlığın gelişimi çocukların zamanından önce okuma ve yazmayı öğrenmesi olmayıp dinleme, konuşma, sesbilgisel farkındalık ve yazı farkındalığı gibi okuma yazmaya temel oluşturacak temel becerileri doğumdan okulöncesi döneme kadar uzayan süreçte geliştirmesidir (Bee ve Boyd, 2009). Çocukların erken yaşlarda içinde bulundukları okul ve aile ortamları arasındaki etkileşimler gelişimin her alanında belirleyici olup erken okuryazarlık gelişiminde de hem eğitim kurumlarının uyaranları hem de aile ortamının etkileşimsel zenginliği etkilidir. Nitekim Teale ve Sulzby (1986) de sözel ve yazılı dili oluşturan öğelerin eş zamanlı olarak ve ailenin çocuğa sunduğu deneyimler ve çocuğun model alma süreçleriyle geliştiğini ifade etmektedir. Bu anlayışa göre erken okuryazarlık becerileri çocuğun dünyaya gelmesi ile gelişmeye başlayan ve aile içinde doğal deneyimlerden beslenen bir süreçtir (Teale ve Sulzby, 1986; Whitehurst ve Lonigan, 1998). Bu açıdan, okul öncesinde çocukların erken okuryazarlık becerilerinin geliştirilebilmesi ve okuldaki kazanımların evde de devam etmesi için ailelerin bilgi ve becerilerini artıran destekleyici çalışmalara katılmaları önem taşımaktadır.

Okulöncesi dönemde erken okuryazarlık becerilerini desteklemeye yönelik aile temelli dil destek programlarında ebeveynlerin gelir ve eğitim durumu, evdeki çocuk sayısı, annenin çalışma durumu ya da çocuğun devam ettiği okul türü gibi çeşitli demografik özelliklerin önemli olduğu bilinmektedir. Ancak, farklı sosyoekonomik gruplardaki ailelerin katılımı konusunda tartışmalar hala devam etmektedir (Barratt-Pugh ve Rohl, 2016; Carpentieri vd, 2011). Karşılıklı konuşma ve çocuğa yazılı materyallerle etkileşim gibi bileşenleri olan programlara; üst sosyoekonomik gruplardan ailelerin katılımı daha kolay ve yüksek olmaktadır (Krijnen, Van Steensel, Meeuwisse, Jongerling ve Sabine, 2019). Gelir durumu ve eğitim düzeyi düşük olan alt sosyoekonomik sınıflardan ailelerin ise bu tür programlara katılımları teşvik edilse dahi sınırlı kalmaktadır (Sonnenschein, Brody ve Munsterman, 1996'dan akt. Bennett, Weigel ve Martin, 2002). Bu konuda bazı aileler de düzenli desteğe ihtiyaç duymaktadır (Barratt-Pugh ve Rohl, 2016). Sadece alt sosyoekonomik katmandaki ailelere odaklanan bazı programlar (Muslugüme, 2016; Aram, Fine ve Ziv, 2013) toplumun farklı kesimlerindeki aileler arasındaki dilsel uyaran farklııklarını (Avcı, 2013) azaltabilir. Ne var ki dil becerilerini destekleyici bir ev ortamının toplumun genelinde düşük olduğu ve aslında sosyoekonomik düzey fark etmeksizin tüm okulöncesi dönem çocuklarının sistematik müdahalelere ihtiyaç duyabileceği de vurgulanmaktadır (Ergül, Dolunay Sarıca, Akoğlu ve Karaman, 2017). Dolayısıyla düşük gelir veya eğitim düzeyindeki riskli gruplar için hazırlanan yoğun müdahale programlarının yanı sıra herhangi bir risk grubunu hedeflemeden, aileleri çocuklarının dil rehberi olarak tanımlayan evrensel nitelikli programlar da yaygınlaşmaktadır (Doyle, 2012).

Okulöncesi çocuklarının erken okuryazarlık becerilerini desteklemek için hem uluslararası hem de ulusal alanyazında çeşitli çalışmalar yapılmaktadır. Bu çalışmalarda gerek kültürel duyarlıık gerekse sürdürülebilir etkiler açısından aile katılımının önemi vurgulanmaktadır (Bennett vd., 2018). Zira aileyi dâhil etmeyen eğitim çalışmalarından etki beklemek ve verim almak oldukça zordur. Bu nedenle dil becerilerinin okul dışında desteklenmesine yönelik pek çok eğitsel müdahale, uluslararası alanyazının 'aile okuryazarlığı' kavramı ile işaret ettiği programlar şeklinde aile temelli olarak geliştirilmektedir. Ancak, bu türden eğitsel çalışmalara aileleri dâhil etmek tek başına yeterli olmayıp ailelerin planlama sürecine de dâhil edilmesi elzem görünmektedir. Türkiye'de aileye yönelik programların incelendiği bazı güncel çalışmalar bulunmakla beraber (Kızıltaş, 2009; Muslugüme, 2016; Kınık, Okyay ve Aydoğan, 2016) birçok programda ailelerin görüşlerinin uygulama sonrasında alındığı dikkat çekmektedir. Gerek ulusal gerekse uluslararası alanyazına yansıyan bu programların hem çocukların erken okuryazarlığa yönelik becerilerini desteklediği (Özen Altınkaynak, 2019) hem de ev ortamında ebeveynlerin uygulamalarının niteliğini arttırdığı görülmüştür (Doyle ve Zhang, 2011; Aram, Fine ve Ziv, 2013; Samiei, Bush, Sell ve Imig, 2016; Niklas, Cohrssen ve Tayler, 2016). Ancak, bu programların konu edildiği araştırmalar sonlandıktan sonra ailelerin bu uygulamaları devam ettirip 
ettirmediği hala belirsizliğini korumaktadır (la Rie, Van Steensel ve Van Gelderen, 2017). Bu durum eğitim programlarından beklenen özellikler olan uygulamada süreklilik ve kazanımlarda kalıcılı̆ın sağlanmasına yönelik soru işaretleri oluşturmaktadır. Oysa aile okuryazarlığı programlarında ebeveynlerin öğrendiği erken okuryazarlığı destekleyici uygulamaları günlük rutinlere yedirerek gerçekleştirmeleri yani programa katılım sonrasında da uygulamayı sürdürmeleri beklenmektedir (Saracho, 2017). Zira kitap gibi materyallerle etkileşime girerek yeni sözcükler ve yapılarla karşılaşan çocuğun sözel dili desteklenmesine rağmen edinilen yeni bilgiler günlük yaşamın diğer alanlarına yedirilmediği zaman elde edilen verim sınırlanmaktadır (Gregory, 2005'ten akt. Hill ve Diamond, 2013). Erken okuryazarlık becerilerine yönelik dil destek çalışmalarında edinilen kazanımların ebeveyn ve çocuk açısından sürekliliği ve kalıcılığının sağlanabilmesi için planlama aşamasında, bu türden programların temel katılımcısı olan ailelerin fikirlerine başvurmak etkili olabilir.

Erken okuryazarlıkta aile temelli uygulamaların çocuklar açısından olumlu etkileri vurgulanmakla birlikte çeşitli çalışmalar bu programlarda düşük etki büyüklüklerine ve karmaşık bileşenlerin bu uygulamaların çıktılarını azalttığına işaret etmektedir (Barratt-Pugh ve Rohl, 2016; Van Steensel, McElvany, Kurvers ve Herppich, 2011). Ailelerin okulöncesi dönemde çocuklarının erken okuryazarlık becerilerini desteklemek için ne tür programlara katılabileceklerinin, bu programlardan neler beklediklerinin ve onları engelleyen durumların anlaşılmasıyla çocukların dil becerilerini destekleyen ve etkili olan eğitsel çalışmalar geliştirilebilecektir. Nitekim aile okuryazarlı̆ıı kavramı ile temellendirilen bu tür çalışmalarda ailelerin katıımını belirleyen unsurların (Doyle, 2012; Doyle ve Zhang, 2011) yanı sıra aileler ve çocukların erken okuryazarlık konusundaki etkinlikleri nasıl uyguladıklarının ve mevcut ev ortamlarına bunları nasıl adapte ettiklerinin incelenmesi önerilmektedir (Van Steensel vd, 2011). Bu bağlamda, erken okuryazarlığa yönelik dil destek programlarında ailelerin "ne" yapmak istediklerinin ve bu çalışmaları "nası" yapabileceklerinin incelenmesi alanyazına katkı sağlayabilir. Bu çalışmanın amacı da okulöncesi dönemde çocuğu olan ailelerin erken okuryazarlık becerilerine yönelik dil destek çalışmaları konusundaki tercihlerini betimlemektir. Dolayısıyla bu araştırmada şu sorulara cevap aranmıştır:

- Okulöncesi dönemde çocuğu olan ailelerin erken okuryazarlık becerilerine yönelik dil destek çalışmaları konusunda tercihleri nelerdir?

- Erken okuryazarlık becerilerine yönelik dil destek çalışmaları konusunda ailelerin tercihleri demografik özelliklere göre farklılaşmakta mıdır?

\section{Araştırmanın Modeli}

\section{Yöntem}

Nicel araştırma desenlerinden tarama yöntemi ile yürütülmüş betimsel bir araştırmadan üretilen bu çalışmada ailelerin dil destek çalışmaları konusundaki tercihlerine odaklanılmıştır. Tarama araştırmaları, evrenden seçilen bir örneklemde yapılan çalışmalarla evrendeki eğilim, tutum veya görüşlerin betimlenmesini içerir (Creswell, 2016). Dil destek çalışmaları, ebeveynlerin okul saatleri dışında çocukları ile gerçekleştirecekleri ve çocukların erken okuryazarlık becerilerini destekleyici etkinlikleri öğrenebilecekleri eğitsel çalışmaları kapsamaktadır. Uluslararası alanyazında bu çalışmalar aile okuryazarlığı programları olarak adlandırılmakta (Barratt-Pugh ve Rohl, 2016) ancak ulusal alanyazında henüz bu kavram yerleşmediği için bu çalışmada 'dil destek çalışması' kavramı aile okuryazarlığı programı ile eş anlamda kullanılmıştır.

\section{Örneklem}

Araştırmanın evrenini 2018-2019 Eğitim-Öğretim yılında Eskişehir ili Tepebaşı ilçesindeki özel ve resmi anaokulları ile ilkokul bünyesindeki anasınıflarına kayıtlı, anadili Türkçe olan ve normal gelişim gösteren 5-6 yaşlarındaki 2496 çocuğun ebeveyni oluşturmuştur. Araştırmanın katılımcıları, ilçe Millî Eğitim Müdürlüğünden edinilen okul ve sınıf listeleri kullanılarak küme ve ulaşılabilir örnekleme yöntemleri ile belirlenmiştir (Neuman, 2006). Örneklem büyüklügünün tespitinde Krejcie ve Morgan'ın (1970) formülüne dayalı oluşturulan örneklem tablosundan faydalanılarak özel ve resmi okullar için ayrı ayrı örneklem büyüklüğü hesaplanmıştır. Evreni oluşturan resmi okullarda 5-6 yaşlarındaki öğrenci sayısı 50'den fazla olan 22 okul arasından önce tesadüfi olarak 14 okul, ardından 
bu okullardan tesadüfi olarak 2 tane şube seçilerek bu sınıflardaki tüm çocukların ebeveynlerine ulaşmak hedeflenmiştir (Toplam 557 ebeveyn). Özel okullarda ise araştırmaya katılmayı gönüllü olarak kabul eden 10 özel okuldan 344 çocuğun ebeveynine ulaşmak hedeflenmiştir. Böylece özel ve resmi kurumlarda 5-6 yaş grubu sınıflarında çocuğu olan toplam 901 ebeveyne ulaşılmış ancak 688 ebeveynden geri dönüş olmuştur.

Tablo 1.

Örneklemi Oluşturan Katılımcıların Okullara Dağılımı

\begin{tabular}{llll}
\hline & & $\mathbf{N}$ & $\%$ \\
\hline Anaokulu & Özel & 134 & 20,9 \\
& Devlet & 174 & 27,2 \\
\multirow{3}{*}{ ilkokullar (Anasınıfları)) } & Özel & 73 & 11,4 \\
& Devlet & 259 & 40,5 \\
& Toplam & 640 & 100,0 \\
\hline
\end{tabular}

Tablo 1'de görüldüğü gibi eksik veya rastgele doldurulma gibi sebeplerle elenen soru kitapçıklarından sonra özel veya resmi anaokulları ve ilkokul bünyesindeki anasınıflarında 5-6 yaşında çocuğu olan toplam 640 ebeveyn araştırmanın örneklemini oluşturmuştur.

\section{Veri Toplama Araçları}

Bu çalışmaya temel oluşturan yüksek lisans tez araştırmasında, dört farklı bölümden oluşan 'Okulöncesi Dönemde Dil Becerilerine Yönelik Ebeveyn Görüşleri' adlı soru kitapçığı kullanılmıştır. Kitapçık isminde 'erken okuryazarlık' kavramı yerine dil becerileri kullanılarak ebeveynlerde oluşabilecek okuma-yazma öğretimi algısını önlemek amaçlanmıştır. Araştırmada kullanılan soru kitapçığı 1) ev ortamında erken okuryazarlığa yönelik bir ölçek, 2) ailelerin erken okuryazarlık konusunda okuldan beklentileri, 3) ailelerin dil destek çalışmalarına yönelik tercihleri ve 4) demografik özelliklere ilişkin soruları içermektedir. Bu makale kapsamında ise soru kitapçığının üçüncü bölümünde yer alan dil destek çalışmalarına yönelik aile tercihlerine odaklanılmış ve demografik özellikler ışığında ailelerin tercihleri analiz edilmiştir. Ailelerin tercihleri konusundaki sorular araştırmacılar tarafından hazırlanmış olup önce alanyazındaki aile temelli programlar incelenmiştir. Bu programlar, odaklandıkları erken okuryazarlık becerilerine, çalışmalar sırasında kullanılan materyallere, ailelerin bilgilendirildikleri konulara, uygulamalarda kimlerin rol aldığına, etkinlikler sırasında çocuğa rehberlik edecek kişiye, ailelerin bilgilendirilme şekillerine ve uygulama süresine göre çeşitlenmektedir. Bu programların özellikleri doğrultusunda ailelerin dil destek çalışmalarına yönelik tercihlerini ortaya koyacak kapalı uçlu toplam sekiz soru geliştirilmiştir. Demografik özellikler bölümü ise yine alanyazına dayalı olarak çocuğa, ebeveynlere ve genel aile özelliklerine ilişkin sorular içermiştir.

Soru kitapçı̆̆ında araştırmacıların geliştirdiği tüm bölümler $(2,3,4)$ hazırlandıktan sonra küçük bir grupla pilot uygulama yapılmıştır. Hazırlanan soruların sıralaması, anlaşılırlı̆ı, değiştirilmesi veya eklenmesi gereken ifadeler ve uygulama süresi bu ön uygulama ile belirlenip gerekli düzeltmeler yapıldıktan sonra kapsam geçerliği için altı alan uzmanı, bir Türkçe dil uzmanı ve bir ölçme değerlendirme uzmanından görüş alınmıştır. Uzman görüşleri doğrultusunda yapılan düzeltmeleri takiben 75 kişi ile ikinci pilot uygulama yapılmış ve soru kitapçığı uygulamaya hazır hale getirilmiştir. Pilot uygulamaya katılan ailelerin bulunduğu okullar araştırma evreni dışında bırakılmıştır.

\section{Veri Toplama Süreci}

Araştırmanın veri toplama aşaması Üniversite Etik Kurulu ve Millî Eğitim Bakanlığından gerekli izinler alındıktan sonra 2018-2019 Sonbahar döneminde gerçekleştirilmiştir. Bu süreçte araştırmacı önce örnekleme giren okullara giderek okul yöneticilerini ve okulöncesi öğretmenlerini araştırma hakkında bilgilendirmiştir. Okul yöneticilerinin de onayını aldıktan sonra ailelere elden ulaştırmaları için öğretmenlere soru kitapçıkları, gönüllü katılım formları, bilgi formları ve boş zarflar teslim 
etmiştir. Aileler evde doldurdukları soru kitapçıkları ve imzalı onay formlarını sınıf öğretmenlerine ayrı ayrı kapalı zarflar içinde ulaştırmış ve araştırmacı bu zarfları okula giderek öğretmenlerden teslim almıştır. Veri toplama süreci toplamda yedi haftalık bir zaman diliminde tamamlanmıştır.

\section{Veri Analizi}

Veri analizinde betimsel istatistikler, nonparametrik testler ve kümeleme analizine başvurulmuş ve IBM SPSS 22.0 paket programından faydalanılmıştır. Soru kitapçıklarının tamamı bilgisayar ortamına aktarılmadan önce kontrol edilmiştir. Ebeveynlerin vermiş oldukları yanıtların frekans ve yüzde değerleri belirlenmiş; alanyazına dayalı olarak ailelerin tercihlerinin bazı demografik değişkenlere göre farklılaşıp farklılaşmadığını anlamak için ki-kare bağımsızlık testi yapılmıştır. Veri analizinde bazı cevap kategorileri birleştirilerek ki kare analizinin ön şartları sağlanmıştır. Ki-kare analizinde önceki seçeneklerle birleştirilemeyen "diğer" seçenekleri analiz dışında tutulmuştur. Demografik değişkenler arasında yer alan ebeveyn çalışma ve eğitim durumları, yurt dışı ve şehir dışı tatiline çıkma sayısı, gelir, anne çalışma durumu, çocuğun devam ettiği okul türü (özel veya devlet) ve okulun bulunduğu mahalle ile kümeleme analizi yapılarak ailelerin sosyoekonomik durumunu gösteren bir sosyoekonomik katman (SEK) değişkeni elde edilmiştir. Bu değişken kullanılarak alt, orta ve üst sosyoekonomik katmanlardaki ebeveynlerin tercihleri karşılaştırılmıştır.

\section{Etik Kurulu İzni}

Kurul adı = Anadolu Üniversitesi Etik Kurulu

Karar tarihi $=5 / 05 / 2018$

Belge sayı numarası $=54380210-050.99$

\section{Bulgular}

Ailelerin erken okuryazarlık becerilerine yönelik dil destek çalışmaları konusundaki tercihleri ve bu tercihlerin demografik özelliklere göre farklılaşma durumları sekiz alt başlık altında incelenmiştir. Ailelerin dil destek çalışmaları kapsamında tercihleri; bilgiye ihtiyaç duydukları konular, çocuklarına kazandırmak istedikleri beceriler, bilgilendirme yöntemi, çocuklarıyla kullanacakları materyaller, çalışmalara ayırabilecekleri süre, çalışmaların diğer katılımcılar, etkinliklerde çocuklara rehberlik edecek kişiler ve çalışmalara katıımlarını engelleyen durumlardan oluşmaktadır.

\section{Ailelerin Bilgiye İhtiyaç Duyduğu Konular}

Ailelerin erken okuryazarlığa yönelik dil destek çalışmalarında ne tür bilgiye ihtiyaç duyduklarını belirlemek için "Okulöncesi dönemde çocuğunuz için bir dil destek çalışmasına katılacak olsanız en çok hangi konuda bilgiye ihtiyaç duyarsınız?" şeklindeki bir soru sorulmuştur. Ailelerin dil destek çalışmalarında en çok "çocukla konuşurken eğitici olma ve ona ilgi çekici sorular sorma" konusunda bilgi edinmek istedikleri görülmüştür.

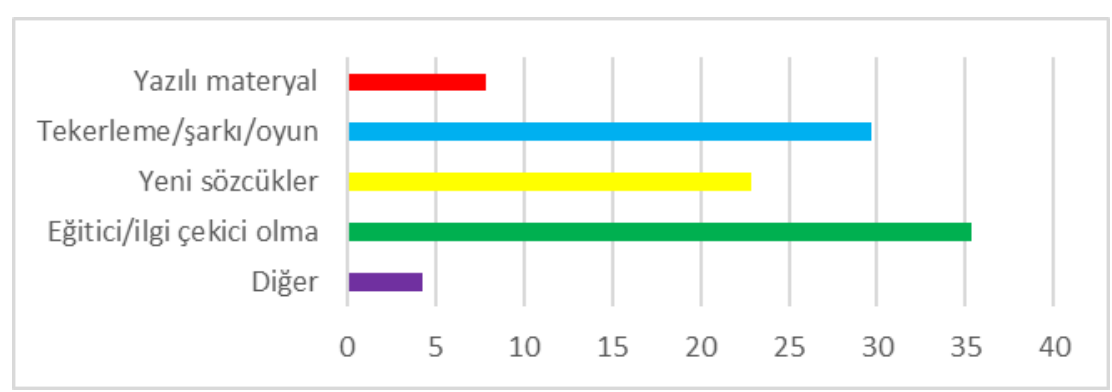

Şekil 1. Ailelerin Bilgiye İhtiyaç Duyduğu Konular

Şekil 1'de görüldüğü gibi ailelerin dil destek çalışmalarında en çok bilgiye ihtiyaç duyduğu konular, "eğitici olma ve ilgi çekici sorular" (\%35,3), "tekerlemeler, çocuk şarkıları, parmak oyunları ve bilmeceler kullanarak çocukla vakit geçirme" $(\% 29,7)$ ve "çocuğa yeni sözcükleri veya sözcüklerin seslerini öğreten oyunları veya etkinlikleri uygulama" $(\% 22,9)$ seçeneklerinden oluşmaktadır. Diğer 
taraftan, çocuğa uygun yazılı materyal ve kitapların seçimi ve bunların ilgi çekici şekilde okunması $(\% 7,8)$ konularında bilgiye ihtiyaç duyduğunu belirten ailelerin oranı ise daha düşüktür. Diğer seçeneğinde yer alan az sayıda aile ise "yeni şeyler öğrenmeye ihtiyacı olmadığını", seçeneklerde sunulanlardan farklı konularda veya tüm konularda bilgiye ihtiyaç duyduğunu belirtmiş̧ir.

Tablo 2.

Ailelerin Bilgi ihtiyaçlarının Demografik Özelliklere göre Dağııımı

\begin{tabular}{|c|c|c|c|c|c|c|c|c|c|c|}
\hline \multirow{3}{*}{\multicolumn{2}{|c|}{ Demografik Özellikler }} & \multicolumn{9}{|c|}{ Ailelerin Bilgi İhtiyaçları } \\
\hline & & \multicolumn{2}{|c|}{$\begin{array}{l}\text { Yazılı } \\
\text { materyal }\end{array}$} & \multicolumn{2}{|c|}{$\begin{array}{l}\text { Tekerleme } \\
\text { şarkı oyun }\end{array}$} & \multicolumn{2}{|c|}{$\begin{array}{l}\text { Yeni } \\
\text { sözcükler }\end{array}$} & \multicolumn{2}{|c|}{$\begin{array}{l}\text { Eğitici/ } \\
\text { ilgi çekici } \\
\text { olma }\end{array}$} & \multirow{2}{*}{$\begin{array}{l}\text { Toplam } \\
\mathrm{f}\end{array}$} \\
\hline & & $\mathrm{f}$ & $\%$ & $f$ & $\%$ & $\mathrm{f}$ & $\%$ & $f$ & $\%$ & \\
\hline \multirow[t]{4}{*}{ Kurum Yapısı } & Anaokulu & 18 & 6,2 & 97 & 33,3 & 64 & 22,0 & 112 & 38,5 & 291 \\
\hline & ilkokul & 31 & 9,9 & 91 & 29,0 & 81 & 25,8 & 111 & 35,4 & 314 \\
\hline & Toplam & 49 & 8,1 & 188 & 31,1 & 145 & 24,0 & 223 & 36,9 & 605 \\
\hline & & \multicolumn{9}{|c|}{$\left(x^{2}=4,771 \quad s d=3 \quad p=0,189\right)$} \\
\hline Okulöncesi & Hiç & 9 & 5,4 & 49 & 29,5 & 41 & 24,7 & 67 & 40,4 & 166 \\
\hline Eğitim & 1 sene & 24 & 12,4 & 62 & 32,0 & 43 & 22,2 & 65 & 33,5 & 194 \\
\hline \multirow[t]{3}{*}{ Süresi } & $2+$ sene & 15 & 6,6 & 70 & 31,0 & 54 & 23,9 & 87 & 38,5 & 226 \\
\hline & Toplam & 48 & 8,2 & 181 & 30,9 & 138 & 23,5 & 219 & 23,5 & 586 \\
\hline & & \multicolumn{9}{|c|}{$\left(x^{2}=8,044 \quad s d=6 \quad p=0,235\right)$} \\
\hline \multirow[t]{6}{*}{ Anne Mesleği } & Ev hanımı & 25 & 9,5 & 72 & 27,4 & 72 & 27,4 & 94 & 35,7 & 263 \\
\hline & Diğer & 11 & 9,0 & 38 & 31,1 & 25 & 20,5 & 48 & 39,3 & 122 \\
\hline & Profesyonel & 13 & 6,1 & 73 & 34,4 & 47 & 22,2 & 79 & 37,3 & 212 \\
\hline & Toplam & 49 & 8,2 & 183 & 30,7 & 144 & 24,1 & 221 & 37,0 & 597 \\
\hline & & \multicolumn{9}{|c|}{$\left(x^{2}=6,123 \quad s d=6 \quad p=0,410\right)$} \\
\hline & Alt & 25 & 9,2 & 78 & 28,7 & 76 & 27,9 & 93 & 34,2 & 272 \\
\hline Sosyoekonomik & Orta & 13 & 6,7 & 58 & 30,1 & 37 & 19,2 & 85 & 44,0 & 193 \\
\hline \multirow[t]{3}{*}{ Katman } & Üst & 11 & 7,9 & 52 & 37,1 & 32 & 22,9 & 45 & 32,1 & 140 \\
\hline & Toplam & 49 & 8,1 & 188 & 31,1 & 145 & 24,0 & 223 & 36,9 & 605 \\
\hline & & \multicolumn{9}{|c|}{$\left(x^{2}=10,869 \quad s d=6 \quad p=0,093\right)$} \\
\hline
\end{tabular}

Tablo 2'de görüldüğü gibi ailelerin erken okuryazarlık konulu dil destek çalışmalarında bilgi intiyacına yönelik tercihlerinde çocuklarının devam ettiği kurum yapısına, okulöncesi eğitim geçmişine, anne mesleğine ve ailenin sosyoekonomik durumuna göre istatistiksel açıdan anlamlı bir fark yoktur $(p>0,05)$. Diğer bir ifade ile çocuğu özel veya devlet okuluna gidenler, çocuğu daha önce farklı sürelerle okul öncesi eğitim almış olanlar veya olmayanlar, annelerin farklı meslek gruplarından olduğu aileler ve orta, alt ya da üst sosyoekonomik katmanlardan aileler dil destek çalışmalarında intiyaç duydukları bilgi konusunda benzer yönde cevaplar vermişlerdir.

\section{Çocuklara Kazandırılacak Beceriler}

Ailelere okulöncesi dönemdeki dil destek çalışmalarının çocuklarına en çok hangi becerileri kazandırmasını istedikleri sorulmuştur. Ebeveynler için çocuklarının konuşarak kendilerini ifade etmesi ve dinlemesi en önemli beceri olarak görünmektedir. 


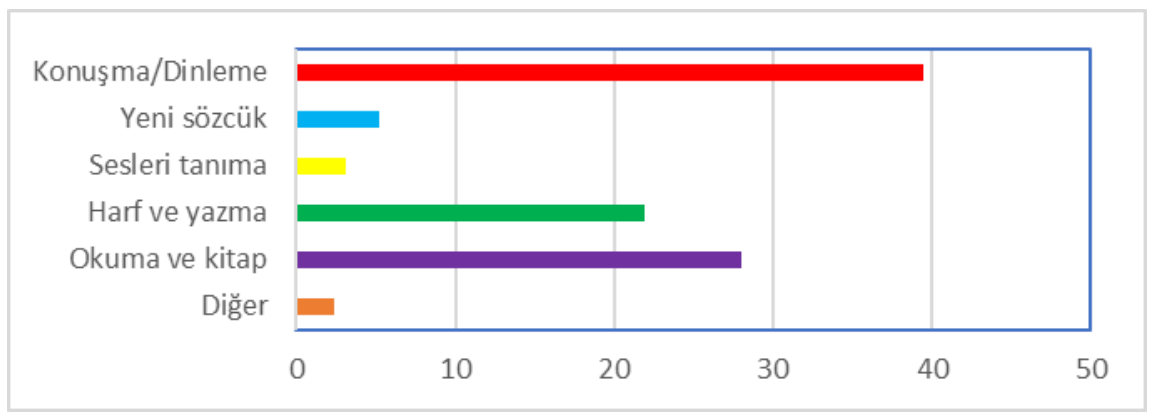

Şekil 2. Çocuklara Kazandırılacak Beceriler

Şekil 2'ye göre aileler, erken okuryazarlık konulu dil destek çalışmalarında "konuşma ve dinleme" $(\% 39,5)$ becerilerinden sonra çocuklarına en yüksek oranda "okumaya ve kitaplara ilgi duyma" (\%28) ve "harfleri tanıma ve yazmaya ilgi duyma" (\%21,9) becerilerinin kazandırılmasını tercih etmişlerdir. Tercihler arasında en düşük oranda ise "yeni sözcükler öğrenme" ve "sözcüklerin içindeki sesleri tanıma" becerileri yer almaktadır. "Diğer" seçeneğini işaretleyen bazı aileler ise dil destek çalışmaları kapsamında çocuklarına birden fazla becerinin kazandırılmasını vurgulamıştır.

Tablo 3.

Çocuklara Kazandırılacak Becerilerin Demografik Özelliklere Göre Dağııımı

\begin{tabular}{|c|c|c|c|c|c|c|c|c|c|c|c|c|}
\hline \multirow[b]{3}{*}{ Demografik Özellik } & & \multicolumn{11}{|c|}{ Çocuklara Kazandırılacak Beceriler } \\
\hline & & \multicolumn{2}{|c|}{$\begin{array}{l}\text { Konuşma/ } \\
\text { Dinleme }\end{array}$} & \multicolumn{2}{|c|}{$\begin{array}{l}\text { Yeni } \\
\text { sözcük }\end{array}$} & \multicolumn{2}{|c|}{$\begin{array}{l}\text { Sesleri } \\
\text { tanıma }\end{array}$} & \multicolumn{2}{|c|}{$\begin{array}{l}\text { Harf ve } \\
\text { yazma }\end{array}$} & \multicolumn{2}{|c|}{$\begin{array}{l}\text { Okuma ve } \\
\text { kitap }\end{array}$} & \multirow{2}{*}{$\begin{array}{l}\text { Toplam } \\
\mathrm{f} \\
\end{array}$} \\
\hline & & $f$ & $\%$ & $f$ & $\%$ & $f$ & $\%$ & $f$ & $\%$ & $f$ & $\%$ & \\
\hline \multirow[t]{4}{*}{ Okul Türü } & Özel & 95 & 47,3 & 14 & 7,0 & 5 & 2,5 & 19 & 9,5 & 68 & 33,8 & 201 \\
\hline & Devlet & 156 & 37,1 & 19 & 4,5 & 15 & 3,6 & 120 & 28,6 & 110 & 26,2 & 420 \\
\hline & Toplam & 251 & 40,4 & 33 & 5,3 & 20 & 3,2 & 139 & 22,4 & 178 & 28,7 & 621 \\
\hline & & $\left(x^{2}=3\right.$ & 0,187 & $s d=4$ & $\mathrm{p}=0$ & $000)$ & & & & & & \\
\hline \multirow[t]{4}{*}{ Kurum Yapısı } & Anaokulu & 123 & 41,3 & 17 & 5,7 & 8 & 2,7 & 59 & 19,8 & 91 & 30,5 & 298 \\
\hline & İlkokul & 128 & 39,6 & 16 & 5,0 & 12 & 3,7 & 80 & 24,8 & 87 & 26,9 & 323 \\
\hline & Toplam & 251 & 40,4 & 33 & 5,3 & 20 & 3,2 & 139 & 22,4 & 178 & 28,7 & 621 \\
\hline & & $\left(x^{2}=3\right.$ & 191 & $s d=4$ & $p=0$, & 526) & & & & & & \\
\hline Okulöncesi Eğitim & Hiç & 70 & 40,9 & 8 & 4,7 & 6 & 3,5 & 46 & 26,9 & 41 & 24,0 & 171 \\
\hline \multirow[t]{4}{*}{ Alma Süresi } & 1 sene & 76 & 37,4 & 11 & 5,4 & 7 & 3,4 & 44 & 21,7 & 65 & 32,0 & 203 \\
\hline & $2+$ sene & 97 & 42,7 & 13 & 5,7 & 6 & 2,6 & 46 & 20,3 & 65 & 28,6 & 227 \\
\hline & Toplam & 243 & 40,4 & 32 & 5,3 & 19 & 3,2 & 136 & 22,6 & 171 & 28,5 & 601 \\
\hline & & $\left(x^{2}=5\right.$ & 411 & $s d=8$ & $\mathrm{p}=0$, & 713) & & & & & & \\
\hline Sosyoekonomik & Alt & 99 & 35,6 & 14 & 5,0 & 12 & 4,3 & 83 & 29,9 & 70 & 25,2 & 278 \\
\hline \multirow[t]{4}{*}{ Katman } & Orta & 85 & 42,9 & 9 & 4,5 & 4 & 2,0 & 45 & 22,7 & 55 & 27,8 & 198 \\
\hline & Üst & 67 & 46,2 & 10 & 6,9 & 4 & 2,8 & 11 & 7,6 & 53 & 36,6 & 145 \\
\hline & Toplam & 251 & 40,4 & 33 & 5,3 & 20 & 3,2 & 139 & 22,4 & 178 & 28,7 & 621 \\
\hline & & $\left(x^{2}=3\right.$ & 1,572 & $d=8$ & $p=0$ & ,000) & & & & & & \\
\hline
\end{tabular}

Tablo 3'te görüldüğü gibi, ailelerin dil destek çalışmalarında çocuklara kazandırılmasını istediği becerilere yönelik tercihleri çocuğun devam ettiği okul türüne $\left(x^{2}(s d=4, n=621)=30,43\right.$, $p=0,00)$ ve ailenin sosyoekonomik durumuna $\left(x^{2}(s d=8, n=621)=31,57, p=0,00\right)$ göre anlamlı düzeyde farklıdır. "Harfleri tanıma ile yazıya ilgi duyma" becerilerini çocuğu devlet okuluna giden aileler daha yüksek oranda tercih ederken, "konuşma ve dinleme" ile "okumaya ve kitaplara ilgi duyma" becerilerini çocuğu özel okula giden aileler daha çok tercih etmişlerdir.

Ailelerin sosyoekonomik durumuna göre çocuklara kazandırılması istenen becerilerde üst ve orta katmandan ailelerin" konuşma ve dinleme" becerilerini alt katmana göre daha yüksek oranda tercih ettiği görülmektedir. "Harfleri tanıma ve yazıya ilgi duyma" becerilerini ise orta ve alt 
katmanlar, üst sosyoekonomik katmana göre daha yüksek oranda tercih etmişlerdir. "Okumaya ve kitaplara ilgi duyma" becerilerinin kazandırılmasını ise üst sosyoekonomik katmandan aileler orta ve alt katmanlara göre daha çok tercih etmişlerdir. Ailelerin çocuklarda görmek istediği becerilere yönelik tercihlerinde çocuğun devam ettiği okulun kurum yapısı ve daha önce okulöncesi eğitim alma süresine göre ise anlamlı bir fark yoktur $(p>0,05)$.

\section{Ailelerin Tercih Ettiği Yöntemler}

Ailelerin "Çocuğunuzla bir dil destek çalışmasına katılacak olsanız evde yapacağınız etkinlikler konusunda eğitimcilerin en çok hangi yöntemle bilgi vermesini tercih edersiniz?" sorusuna verdiği cevaplarda heterojen bir dağılım gözlenmekle birlikte en fazla tercih edilen seçenekler eve bilgi içeren yazılı materyaller gönderilmesi $(\% 30,7)$ ve okulda yapılacak toplantılar $(\% 25,8)$ olmuştur.

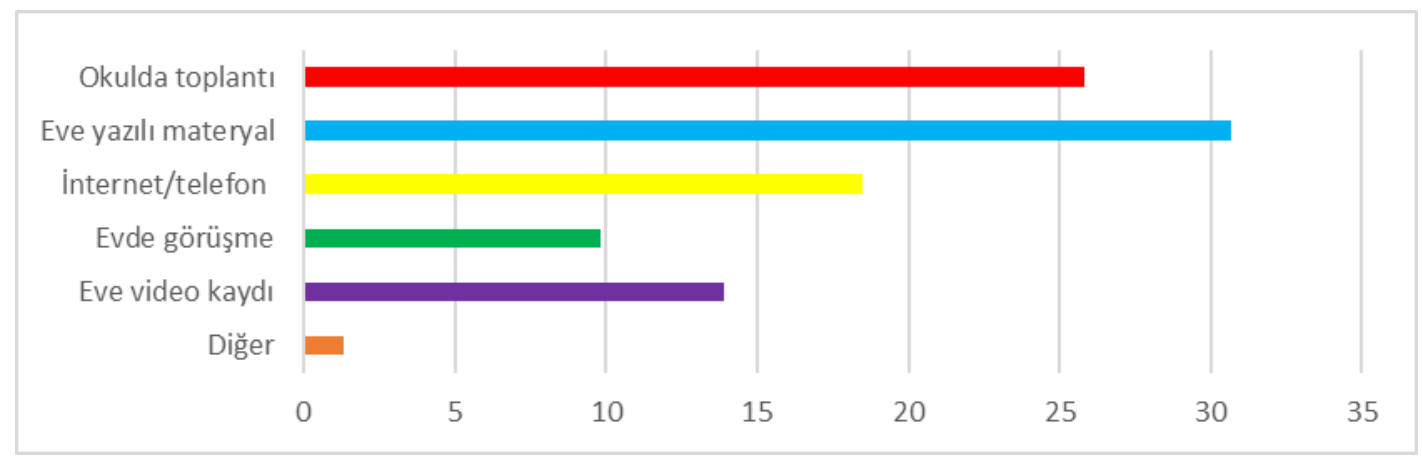

Şekil 3. Ailelerin Tercih Ettiği Yöntemler

Şekil 3'e göre dil destek çalışmalarında kullanılacak bilgilendirme yöntemleri konusunda aileler, internet ve telefon gibi teknolojik araçları $(\% 18,5)$ ve eve video kayıtları gönderilmesini $(\% 13,9)$ daha az oranda tercih etmektedirler. Aileler tarafından en az tercih edilen bilgilendirme yöntemi ise evde yapılabilecek bireysel görüşmelerdir $(\% 9,8)$.

Tablo 4.

Ailelerin Tercih Ettiği Yöntemlerin Demografik Özelliklere Göre Dağılımı

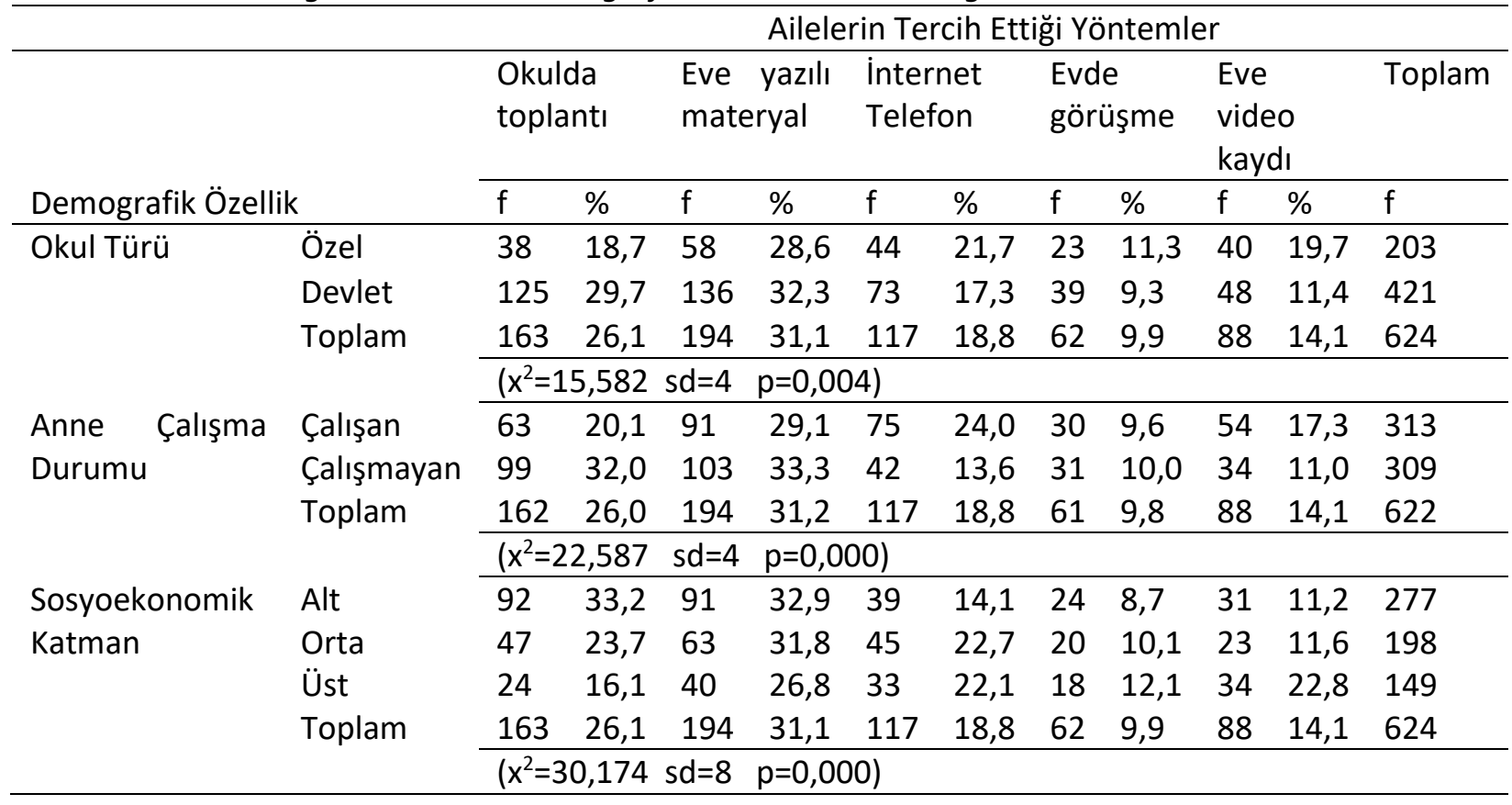

Tablo 4. incelendiğinde ailelerin dil destek çalışmalarında tercih ettikleri yöntemlerde çocukların devam ettiği okul türüne $\left(x^{2}(s d=4, n=624)=15,58, p=0,00\right)$, anne çalışma durumuna 
$\left(x^{2}(s d=4, n=622)=22,58, p=0,00\right)$ ve ailenin bulunduğu sosyoekonomik katmana $\left(x^{2}(s d=8\right.$, $\mathrm{n}=624)=30,17, \mathrm{p}=0,00$ ) göre istatistiksel açıdan anlamlı farklar vardır.

Çocuğun devam ettiği okul türüne göre ailelerin çalışmalardaki yöntem tercihlerine bakıldığında özel okullardaki ailelerin, internet ve telefon gibi teknolojik araçlar ile video kayıtlarını devlet okulundaki ailelerden daha yüksek oranda tercih ettiği görülmektedir. Okulda yapılacak toplantıları çocuğu devlet okuluna giden aileler daha çok tercih etmektedir. Ailenin sosyoekonomik durumuna göre tercihler incelendiğinde de benzer eğilimler gözlenmiştir. Okulda yapılacak toplantı ya da eve gönderilecek yazılı materyalleri tercih etme oranı alt katmanlardaki aileler için üst ve orta gruptan daha yüksektir. Alt sosyoekonomik katmandaki aileler internet/telefon ve video kaydı gibi teknoloji kullanımı içeren yöntemleri ise orta ve üst katmandaki ailelerden daha düşük oranda tercih etmişlerdir. Diğer taraftan tüm grupların en düşük oranda tercih ettiği evde bireysel görüşmeler üst katmandaki aileler tarafından orta ve alt katmana göre daha yüksek oranda tercih edilmiştir. Anne çalışma durumuna göre tercihlerde ise video kayıtları ve internet/telefon gibi araçları çalışan anneler daha yüksek oranda tercih ederken çalışmayan anneler ise okuldaki toplantıları ve eve yazılı materyal gönderilmesini daha yüksek oranda tercih etmişlerdir.

\section{Ailelerin Çocuklarla Kullanacağı Materyaller}

Ailelere katılacakları bir dil destek çalışması kapsamında, çocuklarıyla yapacakları etkinliklerde en çok hangi materyali kullanmayı tercih edecekleri sorulmuştur. Eğitim-öğretimi çağrıştıran eğitsel oyuncak ve basılı materyal gibi seçenekler aileler tarafından daha çok tercih edilmiştir.

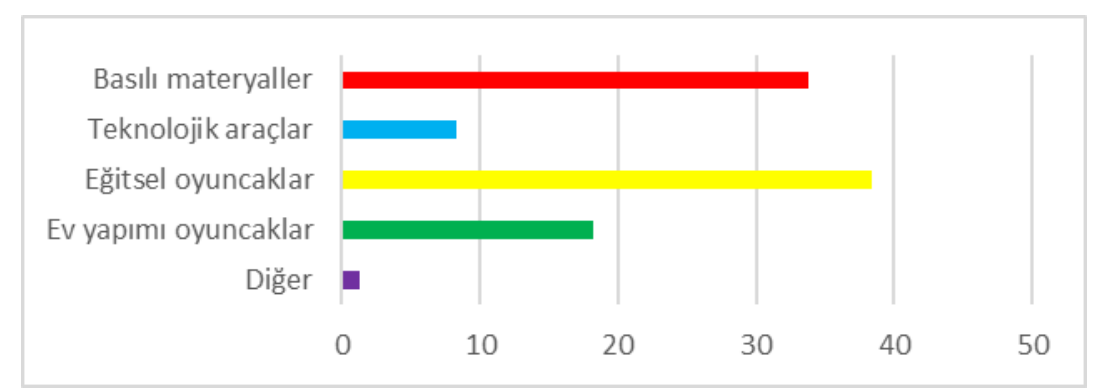

Şekil 4. Ailelerin Çocuklarla Kullanacağı Materyaller

Şekil 4'e göre aileler dil destek çalışmalarında çocuklarıyla en çok eğitsel oyuncakları $(\% 38,4)$ ve dergi, kitap gibi basılı materyalleri $(\% 33,8)$ kullanmayı tercih etmektedir. Bunları evde yapılabilecek materyaller $(\% 18,2)$ takip ederken çocuklarla telefon, tablet ve video gibi teknolojik araçların kullanımı $(\% 8,3)$ az sayıda aile tarafından tercih edilmektedir. Aileler çalışmalarda kullanılacak yöntemlerde teknolojiyi tercih olarak belirtmelerine karşın çocuklarıyla yapacakları çalışmalarda bu türden araçları daha az tercih etmişlerdir.

Tablo 5.

Ailelerin Çocuklarla Kullanacağı Materyallerin Demografik Özelliklere Göre Dağııımı

\begin{tabular}{|c|c|c|c|c|c|c|c|c|c|c|}
\hline \multirow[b]{3}{*}{ Demografik Özellik } & & \multicolumn{9}{|c|}{ Ailelerin Çocuklarla Kullanacağı Materyaller } \\
\hline & & \multicolumn{2}{|c|}{$\begin{array}{l}\text { Basılı } \\
\text { materyal }\end{array}$} & \multicolumn{2}{|c|}{$\begin{array}{l}\text { Teknolojik } \\
\text { araçlar }\end{array}$} & \multicolumn{2}{|c|}{$\begin{array}{l}\text { Eğitsel } \\
\text { oyuncaklar }\end{array}$} & \multicolumn{2}{|c|}{$\begin{array}{l}\text { Ev yapımı } \\
\text { oyuncaklar }\end{array}$} & \multirow{2}{*}{$\begin{array}{l}\text { Toplam } \\
\mathrm{f} \\
\end{array}$} \\
\hline & & $f$ & $\%$ & $f$ & $\%$ & $f$ & $\%$ & $f$ & $\%$ & \\
\hline \multirow[t]{4}{*}{ Çocuğun Cinsiyeti } & Kız & 103 & 34,2 & 25 & 8,3 & 118 & 39,2 & 55 & 18,3 & 301 \\
\hline & Erkek & 111 & 34,3 & 28 & 8,6 & 125 & 38,6 & 60 & 18,5 & 324 \\
\hline & Toplam & 214 & 34,2 & 53 & 8,5 & 243 & 38,9 & 115 & 18,4 & 625 \\
\hline & & $\left(x^{2}=0\right.$ & $042 s$ & $d=3$ & $\mathrm{p}=0$, & & & & & \\
\hline \multirow{3}{*}{$\begin{array}{l}\text { Teknolojik Araçlarla } \\
\text { İlgilenme Süresi }\end{array}$} & $0-2$ saat & 185 & 34,1 & 36 & 6,6 & 219 & 40,3 & 103 & 19,0 & 543 \\
\hline & $2+$ saat & 30 & 35,7 & 17 & 20,2 & 24 & 28,6 & 13 & 15,5 & 84 \\
\hline & Toplam & 215 & 34,3 & 53 & 8,5 & 243 & 38,8 & 116 & 18,5 & 627 \\
\hline
\end{tabular}




\begin{tabular}{|c|c|c|c|c|c|c|c|c|c|c|}
\hline \multirow{3}{*}{$\begin{array}{l}\text { Sosyoekonomik } \\
\text { Katman }\end{array}$} & \multirow[b]{2}{*}{ Alt } & \multicolumn{2}{|c|}{$\left(x^{2}=19,070\right.$} & \multirow{2}{*}{$\begin{array}{c}\mathrm{sd}=3 \\
19\end{array}$} & \multicolumn{2}{|c|}{$p=0,000)$} & \multirow[b]{2}{*}{41,4} & \multirow[b]{2}{*}{42} & \multirow[b]{2}{*}{15,1} & \multirow[b]{2}{*}{278} \\
\hline & & 102 & 63,7 & & 6,8 & 115 & & & & \\
\hline & Orta & 68 & 33,8 & 19 & 9,5 & 71 & 35,3 & 43 & 21,4 & 201 \\
\hline & Üst & 45 & 30,2 & 15 & 10,1 & 58 & 38,9 & 31 & 20,8 & 149 \\
\hline & Toplam & 215 & 34,2 & 53 & 8,4 & 244 & 38,9 & 116 & 18,5 & 628 \\
\hline & & \multicolumn{2}{|c|}{$\left(x^{2}=6,936\right.$} & $s d=6$ & \multicolumn{2}{|c|}{$p=0,327)$} & & & & \\
\hline
\end{tabular}

Tablo 5'te görüldüğü gibi ailelerin yapacakları etkinliklerde kullanacakları materyallere ilişkin tercihlerinde çocuklarının cinsiyetine ve ailenin sosyoekonomik durumuna göre anlamlı bir fark yoktur $(p>0,05)$. Ailelerin materyal tercihlerinde çocuklarının teknolojik araçlarla günlük ilgilenme süresine göre ise anlamlı bir fark vardır $\left(x^{2}(s d=3, n=627)=19,07, p=0,00\right)$.

Çocuğu teknolojiyle günlük 2 saat ve altında ilgilenen ailelerin etkinliklerde kullanmayı en çok tercih ettikleri materyaller eğitsel oyuncaklar, en az tercih ettikleri ise teknolojik araçlardır. Çocuğu teknolojiyle günlük 2 saatten fazla ilgilenen aileler ise en çok basılı materyalleri en az ise ev yapımı oyuncakları tercih etmiştir. Basılı materyalleri ve ev yapımı oyuncakları tercih oranları gruplar arasında benzerken 2 saatten fazla teknolojiyle ilgilenen çocukların ailelerinin; teknolojik araçları seçme oranı diğer ailelerden daha yüksek, eğitsel oyuncakları seçme oranı ise daha düşüktür.

\section{Ailelerin Çalışmalara Ayırabileceği Zaman}

Ailelere "Okulöncesi dönemde bir dil destek çalışmasına katılacak olsanız, çocuğunuzla evde yapacağınız dil etkinliklerine haftada kaç gün zaman ayırabilirsiniz?" sorusu yöneltildiğinde ailelerin çoğunluğu çalışmalara "haftada 1-2 gün" zaman ayırabileceklerini belirtmiştir.

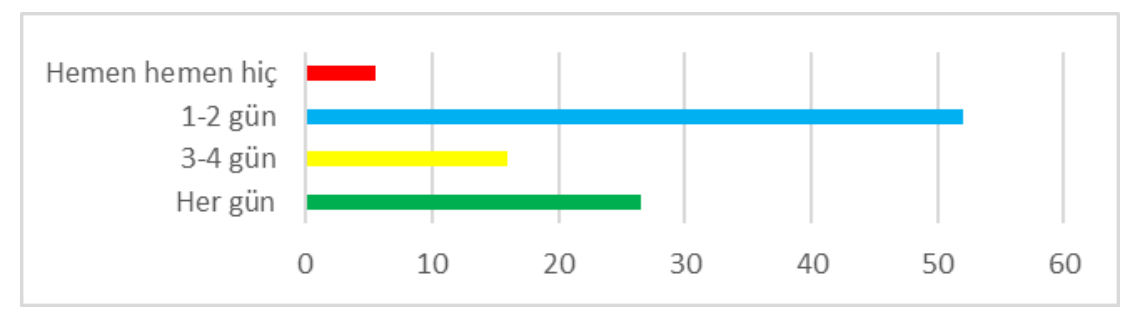

Şekil 5. Ailelerin Çalışmalara Ayırabileceği Zaman

Şekil 5'e göre ailelerin dil destek çalışmaları kapsamında çocukları ile evde yapacakları etkinliklere en çok "haftada 1-2 gün" zaman ayırabilecekleri görülmektedir. Bu tercihi "her gün" ve "haftada 3-4 gün" takip ederken "hiç" zaman ayıramayacak olan aileler de bulunmaktadır.

Tablo 6.

Ailelerin Çalışmalara Ayrılabileceği Zamanın Demografik Özelliklere Göre Dağılımı

\begin{tabular}{|c|c|c|c|c|c|c|c|c|c|c|}
\hline \multirow[b]{3}{*}{ Demografik Özellik } & & \multicolumn{9}{|c|}{ Ailelerin Çalışmalara Ayırabileceği Zaman } \\
\hline & & \multicolumn{2}{|c|}{$\begin{array}{c}\text { Hemen } \\
\text { hemen hiç }\end{array}$} & \multicolumn{2}{|c|}{ 1-2 gün } & \multicolumn{2}{|c|}{ 3-4 gün } & \multicolumn{2}{|c|}{ Her gün } & \multirow{2}{*}{$\begin{array}{c}\text { Toplam } \\
\mathrm{f} \\
\end{array}$} \\
\hline & & $f$ & $\%$ & $f$ & $\%$ & $f$ & $\%$ & $f$ & $\%$ & \\
\hline \multirow[t]{5}{*}{ Kardeş Sayısı } & Tek çocuk & 11 & 4,7 & 115 & 48,9 & 30 & 12,8 & 79 & 33,6 & 235 \\
\hline & 1 kardeş & 18 & 5,6 & 169 & 52,5 & 56 & 17,4 & 79 & 24,5 & 322 \\
\hline & $2+$ kardeş & 6 & 7,5 & 48 & 60,0 & 16 & 20,0 & 10 & 12,5 & 80 \\
\hline & Toplam & 35 & 5,5 & 332 & 52,1 & 102 & 16,0 & 168 & 26,4 & 637 \\
\hline & & \multicolumn{9}{|c|}{$\left(x^{2}=15,943 \quad s d=6 \quad p=0,014\right)$} \\
\hline Anne Çalışma & Çalışan & 19 & 6,0 & 165 & 51,9 & 48 & 15,1 & 86 & 27,0 & 318 \\
\hline \multirow[t]{3}{*}{ Durumu } & Çalışmayan & 16 & 5,0 & 167 & 52,5 & 54 & 17,0 & 81 & 25,5 & 318 \\
\hline & Toplam & 35 & 5,5 & 332 & 52,2 & 102 & 16,0 & 167 & 26,3 & 636 \\
\hline & & \multicolumn{9}{|c|}{$\left(x^{2}=0,772 \quad s d=3 \quad p=0,836\right)$} \\
\hline Baba Eğitim & Ortaokul ve & 10 & 9,3 & 66 & 61,1 & 16 & 14,8 & 16 & 14,8 & 108 \\
\hline
\end{tabular}




\begin{tabular}{|c|c|c|c|c|c|c|c|c|c|c|}
\hline \multirow{5}{*}{ Durumu } & \multirow{2}{*}{\multicolumn{10}{|c|}{ altı }} \\
\hline & & & & & & & & & & \\
\hline & Lise & 17 & 7,1 & 124 & 51,9 & 36 & 15,1 & 62 & 25,9 & 239 \\
\hline & $\begin{array}{l}\text { Lisans ve } \\
\text { üstü }\end{array}$ & 8 & 2,8 & 137 & 48,1 & 50 & 17,5 & 90 & 31,6 & 285 \\
\hline & Toplam & 35 & 5,5 & 327 & 51,7 & 102 & 16,1 & 168 & 26,6 & 632 \\
\hline & & $\left(x^{2}=1\right.$ & 62 & & $p=0,0$ & & & & & \\
\hline Sosyoekonomik & Alt & 15 & 5,2 & 151 & 52,8 & 48 & 16,8 & 72 & 25,2 & 286 \\
\hline Katman & Orta & 16 & 7,9 & 103 & 51,0 & 35 & 17,3 & 48 & 23,8 & 202 \\
\hline & Üst & 4 & 2,7 & 78 & 52,0 & 19 & 12,7 & 49 & 32,7 & 150 \\
\hline & Toplam & 35 & 5,5 & 332 & 52,0 & 102 & 16,0 & 169 & 26,5 & 638 \\
\hline & & $\left(x^{2}=\varepsilon\right.$ & $0 \mathrm{~s}$ & & $=0,188$ & & & & & \\
\hline
\end{tabular}

Tablo 6'da görüldüğü gibi ailelerin çalışmalar kapsamında çocukları ile evde yapacakları etkinliklere ayırabilecekleri zamana yönelik tercihlerinde çocuğun kardeş sayısına $\left(x^{2}(s d=6\right.$, $n=637)=15,94, p=0,01)$ ve baba eğitim durumuna $\left(x^{2}(s d=6, n=632)=19,16, p=0,00\right)$ göre anlamlı bir fark vardır. Baba eğitim durumunun yüksek olması ve ailede çocuğun kardeş sayısının az olması ailelerin çalışmalara ayırabileceği zamanı artıran bir özellik olarak görünmektedir. Ancak, ailelerin zaman ayırma tercihlerinde annenin çalışma durumuna ve ailenin bulunduğu sosyoekonomik katmana göre anlamlı bir fark yoktur $(p>0,05)$.

\section{Çalışmalardaki Diğer Katılımcılar}

Ailelere bir dil destek çalışmasına katılacak olsalar, programa başka kimlerin katılmasını en çok isteyecekleri sorulmuştur. Aileler, çocuklarıyla birlikte katılacakları erken okuryazarlık becerilerine yönelik dil destek çalışmalarına en yüksek oranda aynı evde yaşadıkları eş, kardeş ve büyük ebeveynlerin katılmasını tercih etmişlerdir $(\% 46,9)$.

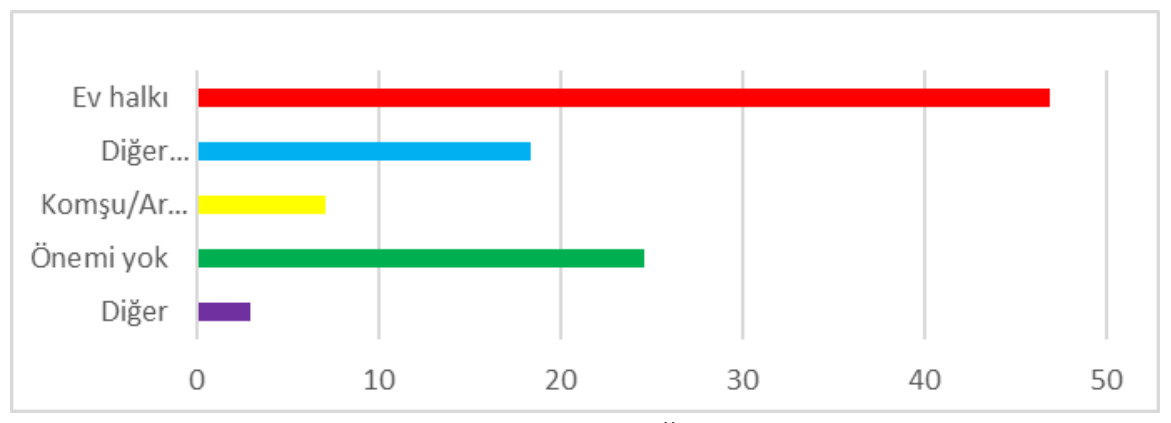

Şekil 6. Çalışmalardaki Diğer Katılımcılar

Şekil 6'ya göre "Çalışmalara kimlerin katılacağının kendileri için önemli olmadığını" belirten ailelerin oranı $\% 24,6$ 'dır. Bu tercihi çocuğun okulundan veya diğer okullardan ailelerin tanıdığı ya da tanımadığı "başka veliler" takip etmiştir. Aileler en düşük oranda ise komşu/arkadaş gibi tanıdıkların dil destek çalışmalarına katılmalarını tercih etmiştir. "Diğer" seçeneğini işaretleyen ailelerin bir kısmı ise alan uzmanlarının çalışmalara katılmasını istemiştir.

Tablo 7.

Çalışmalardaki Diğer Katılımcıların Demografik Özelliklere Göre Dağıımı

\begin{tabular}{|c|c|c|c|c|c|c|c|c|c|c|}
\hline & & \multicolumn{9}{|c|}{ Çalışmalardaki Diğer Katılımcılar } \\
\hline & & \multicolumn{2}{|c|}{ Ev halkı } & \multicolumn{2}{|c|}{$\begin{array}{l}\text { Diğer } \\
\text { veliler }\end{array}$} & \multicolumn{2}{|c|}{ Komşu/arkadaş } & \multicolumn{2}{|c|}{ Önemi yok } & \multirow{2}{*}{$\begin{array}{l}\text { Toplam } \\
\mathrm{f}\end{array}$} \\
\hline \multicolumn{2}{|c|}{ Demografik Özellik } & $f$ & $\%$ & $f$ & $\%$ & $f$ & $\%$ & $f$ & $\%$ & \\
\hline Okulöncesi & Hiç & 79 & 46,7 & 27 & 16,0 & 17 & 10,1 & 46 & 27,2 & 169 \\
\hline Eğitim Alma & 1 sene & 104 & 52,5 & 43 & 21,7 & 11 & 5,6 & 40 & 20,2 & 198 \\
\hline Süresi & $2+$ sene & 108 & 47,0 & 42 & 18,3 & 16 & 7,0 & 64 & 27,8 & 230 \\
\hline
\end{tabular}




\begin{tabular}{|c|c|c|c|c|c|c|c|c|c|c|}
\hline \multirow{5}{*}{$\begin{array}{l}\text { Anne Çalışma } \\
\text { Durumu }\end{array}$} & Toplam & 291 & 48,7 & 112 & 18,8 & 44 & 7,4 & 150 & 25,1 & 597 \\
\hline & & \multicolumn{9}{|c|}{$\left(x^{2}=7,990 \quad s d=6 \quad p=0,239\right)$} \\
\hline & Çalışan & 152 & 49,8 & 61 & 20,0 & 22 & 7,2 & 70 & 23,0 & 305 \\
\hline & Çalışmayan & 146 & 46,9 & 56 & 18,0 & 23 & 7,4 & 86 & 27,7 & 311 \\
\hline & Toplam & 298 & 48,4 & 117 & 19,0 & 45 & 7,3 & 156 & 25,3 & 616 \\
\hline & & \multicolumn{9}{|c|}{$\left(x^{2}=1,939 \quad s d=3 \quad p=0,585\right)$} \\
\hline & Alt & 135 & 49,3 & 60 & 21,9 & 20 & 7,3 & 59 & 21,5 & 274 \\
\hline Sosyoekonomik & Orta & 98 & 49,5 & 33 & 16,7 & 13 & 6,6 & 54 & 27,3 & 198 \\
\hline \multirow[t]{3}{*}{ Katman } & Üst & 66 & 45,2 & 24 & 16,4 & 12 & 8,2 & 44 & 30,1 & 146 \\
\hline & Toplam & 299 & 48,4 & 117 & 18,9 & 45 & 7,3 & 157 & 25,4 & 618 \\
\hline & & \multicolumn{9}{|c|}{$\left(x^{2}=6,181 \quad s d=6 \quad p=0,403\right)$} \\
\hline
\end{tabular}

Tablo 7'de görüldüğü gibi ailelerin çalışmalara katılmasını istedikleri kişilere ilişkin tercihlerinde çocuğun daha önce okulöncesi eğitim alma süresine, annenin çalışma durumuna ve ailenin bulunduğu sosyoekonomik katmana göre anlamlı bir fark yoktur $(p>0,05)$.

\section{Çocuğa Rehberlik Edecek Kişi}

Çalışmalar kapsamında çocukla yapılacak etkinlikleri kimin gerçekleştirebileceğini incelemek için ailelere "Okulöncesi dönemde bir dil destek çalışmasına katılsaydınız yapılacak olan etkinliklerde, çocuğunuza rehberlik etmek için ailenizde en çok kim zaman ayırırdı?" sorusu yöneltilmiştir. Aileler büyük oranla "anne" rehberliğini tercih etmiştir.

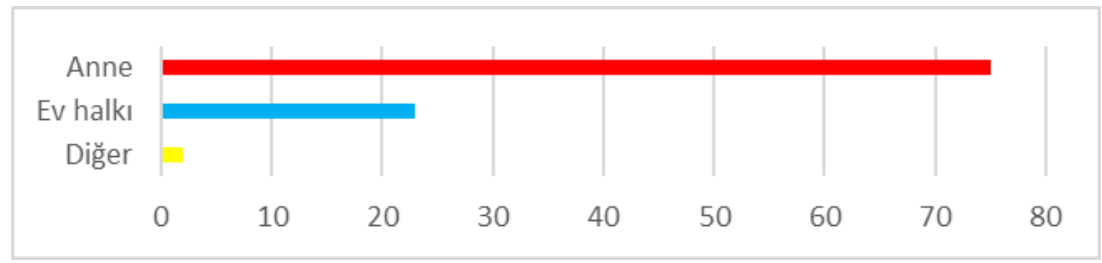

Şekil 7. Çocuğa Rehberlik Edecek Kişi

Şekil 7’ye göre dil destek çalışması kapsamında evde yapılacak etkinliklerde çocuğa rehberlik için zaman ayıracak kişi en yüksek oranda "anne" olmuştur (\%75). Çocuğa dil etkinliklerinde rehberlik için zaman ayıracak baba ve büyük kardeş gibi ev halkı üyelerini tercih oranı ise daha düşüktür. "Diğer" seçeneğini işaretleyen ailelerin bazıları anne-kardeş ya da anne-baba gibi birden fazla rehber yazarken evde çocuğa rehberlik edecek başka kimsenin olmadığını belirtenler de olmuştur.

Tablo 8.

Çocuğa Rehberlik Edecek Kişilerin Demografik Özelliklere Göre Dağııımı

\begin{tabular}{|c|c|c|c|c|c|c|}
\hline & & \multicolumn{5}{|c|}{ Çocuğa Rehberlik Edecek Kişi } \\
\hline \multirow[b]{2}{*}{ Demografik Özellik } & & \multicolumn{2}{|c|}{ Anne } & \multicolumn{2}{|c|}{ Ev halkı } & \multirow{2}{*}{$\frac{\text { Toplam }}{f}$} \\
\hline & & $f$ & $\%$ & $f$ & $\%$ & \\
\hline Anne Çalışma & Çalışan & 226 & 72,4 & 86 & 27,6 & 312 \\
\hline \multirow[t]{3}{*}{ Durumu } & Çalışmayan & 252 & 80,8 & 60 & 19,2 & 312 \\
\hline & Toplam & 478 & 76,6 & 146 & 23,4 & 624 \\
\hline & & $\left(x^{2}=6,044\right.$ & $s d=1$ & $0=0,014)$ & & \\
\hline \multirow[t]{5}{*}{ Anne Mesleği } & Ev hanımı & 223 & 82,6 & 47 & 17,4 & 270 \\
\hline & Diğer & 83 & 65,9 & 43 & 34,1 & 126 \\
\hline & Profesyonel & 167 & 75,2 & 55 & 24,8 & 222 \\
\hline & Toplam & 473 & 76,5 & 145 & 23,5 & 618 \\
\hline & & $\left(x^{2}=13,705\right.$ & $\mathrm{sd}=2 \quad \mathrm{p}$ & $p=0,001)$ & & \\
\hline Sosyoekonomik & Alt & 229 & 81,5 & 52 & 18,5 & 281 \\
\hline Katman & Orta & 134 & 67,3 & 65 & 32,7 & 199 \\
\hline
\end{tabular}




\begin{tabular}{lccccc} 
Üst & 116 & 79,5 & 30 & 20,5 & 146 \\
Toplam & 479 & 76,5 & 147 & 23,5 & 626 \\
\cline { 2 - 6 } & $\left(x^{2}=13,909\right.$ & $\mathrm{sd}=2$ & $\mathrm{p}=0,001)$ & & \\
& &
\end{tabular}

Tablo 8'de görüldüğü gibi ailelerin evde yapacakları etkinlikler sırasında çocuklarına rehberlik edebilecek kişilerde annenin çalışma durumuna $\left(x^{2}(s d=1, n=624)=6,04, p=0,01\right)$, mesleğine $\left(x^{2}(s d=2\right.$, $n=618)=13,70, p=0,00)$ ve ailenin sosyoekonomik durumuna $\left(x^{2}(s d=2, n=626)=13,90, p=0,00\right)$ göre anlamlı bir fark vardır.

Anne çalışma durumuna göre cevap dağılımları incelendiğinde hem çalışan hem de çalışmayan annelerin en çok "anne" rehberliğini seçtiği görülmektedir. Anneyi tercih oranı çalışmayan annelerde, ev halkını tercih oranı ise çalışan annelerde daha yüksektir. Anne mesleğine göre bakıldığında, ev hanımı anneler grubunun yapılacak etkinliklerde çocuğa rehber olarak anneyi seçme oranı, diğer işlerde çalışan anneler grubunun ise çocuğa rehber olarak ev halkından diğer üyelerini seçme oranları daha yüksektir. Sosyoekonomik katmana göre ailelerin rehber tercihlerinde de tüm gruplar en çok annenin rehberlik etmek için zaman ayıracağını belirtmiştir. Anne rehberliğine en çok alt sosyoekonomik katman, ev halkından diğer kişilerin rehberliğine ise en çok orta sosyoekonomik katmandan aileler cevaplarında yer vermişlerdir.

\section{Ailelerin Katılımını Engelleyen Durumlar}

Ailelere, katılacakları dil destek çalışmalarında sorumluluk almalarını en fazla engelleyen durum sorulduğunda yüksek oranda zaman ve enerji yokluğunun aileleri engellediği görülmüştür.

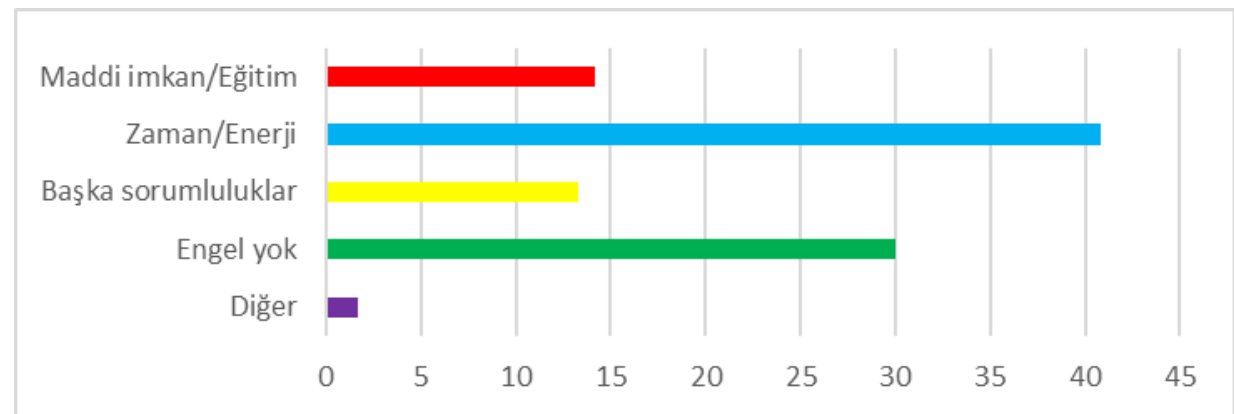

Şekil 8. Ailelerin Katılımını Engelleyen Durumlar

Şekil 8'e göre ailelerin dil destek çalışmalarına katılarak sorumluluk almalarını en çok engelleyen durum yeterli zamana/enerjiye sahip olmamalarıdır (\%40.8). Ailelerin \%30'u ise kendilerini engelleyen bir durumları olmadığını belirtmektedir. Maddi imkânsızlıklar ve eğitimsizlik $(\% 14,2)$, kalabalık bir aile $(\% 13,3)$ gibi nedenler de ailelerin çalışmalara katılarak sorumluluk almalarına engel oluşturmaktadır. Diğer seçeneğini tercih eden aile oranı ise \%1.7 olmuştur.

Tablo 9.

Ailelerin Sorumluluk Almasını Engelleyen Durumların Demografik Özelliklere Göre Dağılımı

\begin{tabular}{|c|c|c|c|c|c|c|c|c|c|c|}
\hline & & \multicolumn{9}{|c|}{ Ailelerin Katılımını Engelleyen Durumlar } \\
\hline \multirow{2}{*}{\multicolumn{2}{|c|}{ Demografik Özellik }} & \multicolumn{2}{|c|}{$\begin{array}{l}\text { Maddi imkân } \\
\text { Eğitim }\end{array}$} & \multicolumn{2}{|c|}{$\begin{array}{l}\text { Zaman } \\
\text { Enerji }\end{array}$} & \multicolumn{2}{|c|}{$\begin{array}{l}\text { Başka } \\
\text { sorumluluklar }\end{array}$} & \multicolumn{2}{|c|}{ Engel yok } & \multirow{2}{*}{$\begin{array}{l}\text { Toplam } \\
f\end{array}$} \\
\hline & & $f$ & $\%$ & $\mathrm{f}$ & $\%$ & $\mathrm{f}$ & $\%$ & $\mathrm{f}$ & $\%$ & \\
\hline \multirow[t]{5}{*}{ Anne Mesleği } & Ev hanımı & 78 & 29,4 & 24 & 9,1 & 56 & 21,1 & 107 & 40,4 & 265 \\
\hline & Diğer & 8 & 6,4 & 88 & 70,4 & 5 & 4,0 & 24 & 19,2 & 125 \\
\hline & Profesyonel & 1 & 0,4 & 144 & 64,3 & 21 & 9,4 & 58 & 25,9 & 224 \\
\hline & Toplam & 87 & 14,2 & 256 & 41,7 & 82 & 13,4 & 189 & 30,8 & 614 \\
\hline & & \multicolumn{9}{|c|}{$\left(x^{2}=236,465 \quad s d=6 \quad p=0,000\right)$} \\
\hline \multirow[t]{2}{*}{ Baba Mesleği } & EUG & 54 & 19,3 & 113 & 40,4 & 35 & 12,5 & 78 & 27,9 & 280 \\
\hline & Esnaf & 27 & 25,2 & 23 & 21,5 & 20 & 18,7 & 37 & 34,6 & 107 \\
\hline
\end{tabular}




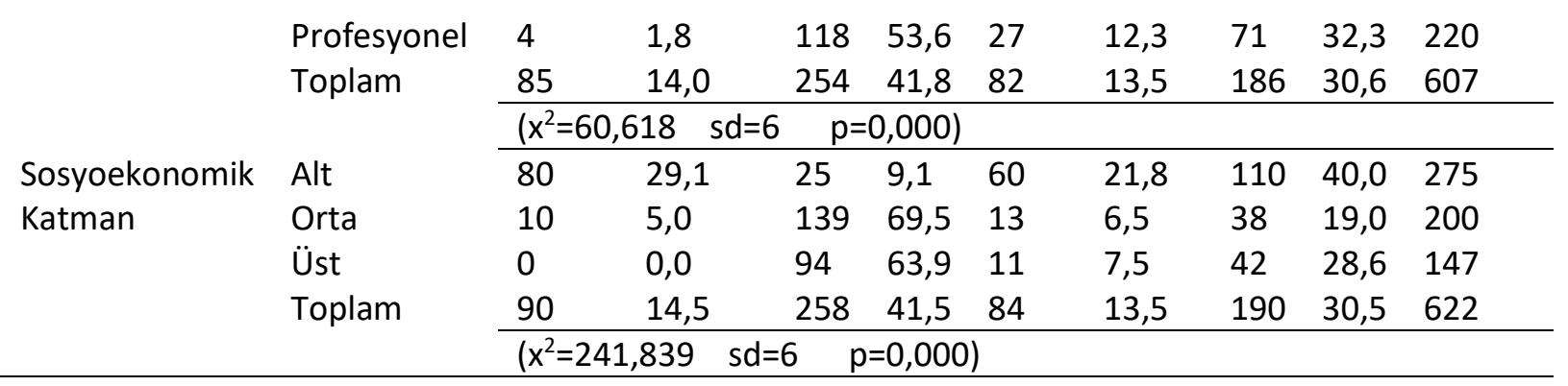

Tablo 9'da görüldüğü gibi ailelerin dil destek çalışmalarında sorumluluk almalarını engelleyen durumlarda; annenin mesleğine $\left(x^{2}(s d=6, n=614)=236,46, p=0,00\right)$, babanın mesleğine $\left(x^{2}(s d=6\right.$, $n=607)=60,61, p=0,00)$ ve ailenin sosyoekonomik durumuna $\left(x^{2}(s d=6, n=622)=241,83, p=0,00\right)$ göre istatistiksel açıdan anlamlı bir fark vardır.

Anne mesleğine göre engel durumlarına bakıldı̆̆ında; herhangi bir işte çalışan anneler en çok zaman ve enerji azlığının sorumluluk almalarını engellediğini belirtirken ev hanımları farklı engellere işaret etmişlerdir. Ev hanımlarının engelleri olmadığını belirtme oranı diğer meslek gruplarından yüksek olsa da başka sorumluluklar ve maddi imkânsızlık/eğitiminin yetersiz olması durumu da bu grubun karşılaştığı engeller arasında görünmektedir. Esnaflıkla uğraşan babaların olduğu aileler en çok "engel yok" seçeneğini, diğer gruplar ise zaman ve enerji yokluğunu çalışmalara katılmaya bir engel olarak göstermiştir. Profesyonellik gerektiren bir mesleği olan babaların olduğu aileler en az maddi imkân ve eğitim yokluğunu, diğer gruplar ise başka sorumlulukları işaretlemişlerdir.

Ailelerin sosyoekonomik durumuna göre dil destek çalışmalarında sorumluluk almalarını engelleyen durumun orta ve üst sosyoekonomik katmandaki aileler için en çok zaman/enerji azlığı olduğu görülmektedir. Alt sosyoekonomik katmandaki aileler ise kendilerini engelleyen bir durum olmadığını yüksek oranda belirtmiş olmasına karşın diğer engellerin de bu gruptaki aileler için önemli olduğu görülmektedir.

\section{Tartışma ve Sonuç}

Bu çalışmada okulöncesi dönemde çocuğu olan ailelerin, erken okuryazarlık becerilerine yönelik dil destek çalışmaları konusundaki tercihleri betimlenmiştir. Araştırmanın bulgularına göre aileler, dil destek çalışmalarında en çok çocuklarıyla konuşurken eğitici ve ilgi çekici olma konusunda bilgi edinmek istemekte ve çocuklarının dinleme ve konuşma becerilerinin desteklenmesine öncelik vermektedir. Çalışmalar sırasında aileler bilgi edinmek için evlerine somut materyaller gönderilmesini tercih etmektedir. Ailelerin büyük kısmı çocuklarıyla yapacakları etkinliklerde eğitsel oyuncakları kullanmayı tercih ederken teknolojik araçları kullanmak isteyenler azınlıktadır. Dil destek çalışmalarına haftada 1-2 gün zaman ayırabileceğini belirten aileler oldukça fazladır. Bu çalışmalara genellikle aynı evde yaşanan diğer aile bireylerinin katılmasını istenirken etkinliklerde çocuğa rehberlik edecek olan kişi çoğunlukla anne olmuştur. Ailelerin çalışmalarda sorumluluk almasını engelleyen yaygın durum ise yeterli zaman ya da enerjilerinin olmamasıdır.

Ailelerin tercihleri demografik özelliklere göre de karşılaştırılmış olup bazı alanlardaki tercihlerde anlamlı farklılıklar olduğu görülmüştür. Sonuç olarak; ailelerin bilgilendirilmek istediği konulardaki tercihleri demografik özelliklere göre değişmezken çocuklarının desteklenmesini istedikleri beceri alanında fark görülmüştür. Alt sosyoekonomik katmandaki aileler, doğrudan okuma yazmaya ilişkin harf ve yazı ilgisi becerilerini daha çok tercih etmiştir. Alt sosyoekonomik katmandaki aileler çalışmalar kapsamında bilgi edinmek için okulda yapılacak toplantıları da üst katmandakilere göre daha çok tercih ederken annelerin çalıştığı, üst sosyoekonomik katmanda teknoloji aracılığıyla bilgilendirilme öne çıkmıştır. Etkinliklerde kullanılacak materyal tercihinde demografik özelliklere göre fark yoktur. Ailelerin çalışmalara ayrılabilecek zaman eğitim durumu yüksek babaların olduğu evlerde daha yüksekken diğer çocukların sayısının yüksek olduğu aileler için daha düşüktür. Etkinliklere katılması istenen kişi tercihlerinde demografik özelliklere göre fark yoktur. Çocuğa rehberlik edecek temel kişi ise tercih oranı değişmekle beraber her zaman annedir. Bu sonuçlara rağmen etkinliklere 
ayrılabilecek zamanda annenin çalışma durumuna göre fark olmaması dikkat çekmektedir. Son olarak orta ve üst sosyoekonomik katmanda zaman/enerji yetersizliği ailelerin çalışmalarda sorumluluk almasını engellerken alt katmanda maddi yetersizlikler, eğitimsizlik, başka sorumluluklar gibi pek çok engel durumu öne çıkmaktadır.

Ailelerin en çok bilgilendirilmek istediği konu, çocukları ile konuşurken eğitici ve ilgi çekici olmaktır. Alanyazına bakıldığında ebeveynlerle yapılan etkinlikler sırasında çocuklarının ilgisiz ve isteksiz olduğunu düşünen aileler olduğunu ortaya koyan bazı araştırmalar görülmektedir (Kızıltaş, 2009; Özen Altınkaynak, 2019). Bu sonuçlar, araştırmada ulaşılan ebeveynlerin en çok çocuklarıyla konuşurken ilgi çekici ve eğitici olmaya ihtiyaç duyduğuna işaret etmektedir. Yetişkinlerin öğrenme güdülerinin bilgiye ihtiyaç duymaları ile ilişkili olduğu (Knowles, 1984) göz önüne alındığında ailelerin hâlihazırda intiyaç duydukları, "çocuklarına karşı ilgi çekici ve eğitici olma" konusunda becerilerin kazandırımasını içeren dil destek çalışmaları planlanması, ailelerin katılımını ve programların etkililiğini arttıracaktır.

Aileler geliştirilecek olan çalışmalarda çocuklarına en çok konuşma ve dinleme becerilerinin, en az ise yeni sözcükler öğrenme ve sesleri tanıma gibi becerilerin kazandırılmasını tercih etmektedir. Erken okuryazarlık becerilerini destekleyici eğitsel çalışmalarda çocuğa kazandırılması istenen beceri alanına ilişkin; çocuğu devlet okuluna devam eden ve alt sosyoekonomik katmandaki aileler, harf ve yazı gibi doğrudan okuma yazmayla ilişkili becerilere daha çok önem vermiş ve çocuklarının ilerideki okul başarısı hakkında daha çok kaygılanarak buna yönelik çalışmalar yapmak istemiştir. Bu sonuç alanyazındaki çeşitli araştırmalarla paralellik göstermektedir. Işıkoğlu Erdoğan (2016) ve Arıcı ve Tüfekci Akcan (2019) tarafından yapılan çalışmalarda, ilkokul mezunu olan annelerin üniversite mezunu olanlara göre çocuklarıyla okuryazarlık öğretimine ilişkin daha çok çalıştıkları ya da okuryazarlığa daha çok önem verdikleri görülmüştür. Bu sonuçlardan yola çıkıldığında, çocuğu devlet okuluna devam eden ya da alt sosyoekonomik katmandaki ailelere yönelik geliştirilecek erken okuryazarlık becerilerini destekleyici programların, tüm becerileri kapsamakla beraber öncelikli olarak harf ve yazı ilgisi gibi becerilere odaklanması önerilebilir.

Aileler çalışmalar kapsamında bilgilendirme yöntemi olarak en çok eve gönderilecek yazııı eğitim materyallerini ve okul toplantılarını tercih etmişlerdir. Bu sonuç hâlihazırda pek çok okulda eve gönderilen bilgilendirme yazıları ve benzeri yollardan aile-okul iletişiminin sağlanmasıyla başka bir anlatımla ailelerin bu bilgilendirme yöntemine aşina olmasıyla açıklanabilir. Ayrıca aileler, erken okuryazarlığa ilişkin ev uygulamalarında da eve gönderilecek nitelikli yazılı materyallerden faydalanabileceklerdir. Dolayısıyla, geliştirilecek programlarda ailelere rehber olacak nitelikte yazılı veya görsel somut kaynaklar hazırlanması önemli görülmektedir. Alanyazın da ebeveynlerin ve diğer aile üyelerinin eğitime dair yazılı materyallere önem verdiğini ortaya koymaktadır (Doyle ve Zhang, 2011). Özellikle çocuğu devlet okuluna giden, annelerin çalışmadığı, alt ve orta sosyoekonomik katmanlardaki ailelerin yazılı materyalleri ve okulda yapılacak toplantıları daha çok tercih etmesi dikkat çekicidir. Evde bireysel görüşmeler ise her sosyoekonomik katmanda daha az tercih edilen bir bilgilendirme yöntemi olup üst katmandaki aileler bu yöntemi diğerlerinden daha çok istemiştir. Internet ve telefon üzerinden bilgi edinme ya da eve gönderilecek video kayıtlarını tercih oranı annelerin çalıştığı ve üst sosyoekonomik katmandaki ailelerde daha yüksek olmuştur. Bu sonuçlardan hareketle; devlet okullarında yürütülecek programlarda eve gönderilecek yazılı materyallere öncelik verilmesi, üst sosyoekonomik katmandaki aileler için de teknolojik araçlardan da faydalanılması önerilebilir.

Çocuklarla evde yapılacak etkinliklerde aileler en çok hazır eğitsel oyuncakları, en az ise teknolojik araçları tercih etmişlerdir. Ebeveynlerin kendileri teknoloji yoluyla bilgilendirilmeyi daha çok tercih ederken çocuklarıyla yapacakları çalışmalarda teknolojik araçları kullanmaya soğuk bakmaktadır. Süreç hakkında video, fotoğraf gibi görselleri içeren mesajlarla yapılan ebeveyn bilgilendirmelerinin olumlu sonuçları olduğunu ifade eden ve ailelerin memnun kaldıklarına değinen çalışmalar alanyazında da bulunmaktadır (Pila, Lauricella and Wartella, 2018). Özellikle yurt dışında doğru kullanıldığı takdirde teknolojinin erken okuryazarlık becerilerini desteklediğine işaret eden çalışmalar bulunmakta ve çocukları destekleyici çeşitli yazılım ve oyunlar geliştirilmektedir (Shamir, Korat ve Barbi, 2008; Boeglin-Quintana ve Donovan, 2013; Siew and Tang, 2018; Bringula vd., 2018; 
Hershman vd., 2018; Korat ve Shneor, 2019). Türkiye'de ise ebeveynlerin çocuklarla teknoloji kullanımına yönelik daha mesafeli olduğu görülmektedir. Bir ebeveynin soru kitapçığı üzerine yazdığı aşağıdaki yorum bu dikkat çekici bulguyu destekler niteliktedir:

Gelişen teknoloji eşliğinde çocuklarımızın zihinsel ve görsel hafızalarının hızlı gelişimi açısından bilişim dünyasındaki hangi videolar, hangi uygulamalar daha faydalı olabilir? Örnek, bir çocuğu youtube'un karanlık dünyasına bırakmak mı? Yoksa Android veya app'dan geliştirici oyun ve uygulamaları oynamasına izin vermek mi? Ya da bu dünyadan onu tamamen ayıklamak ve uzak tutmak mı? Geleneksel eğitim metotları zaten etkisiz. Ama bu yeni dünyaya hepimiz yabancıyız. Sonuçları, zamanlaması, nasıl ve nerede kullanılacağını çocuklarımız için bilemiyoruz.

Bu konuda ulaşılan bulgular ailelerin teknolojiyi çocukları ile kullanma konusunda bilgi ve desteğe intiyaç duyduğuna işaret etmektedir. Ailelere teknolojinin doğru kullanımını gösterebilmek adına yapılacak çalışmalarda teknolojik araçlara yer verilmesi önerilebilir. Son yıllarda yapılan çalışmalar da Türkiye' de teknoloji kullanımına ilişkin akademik ilginin başladığını göstermektedir (Türe Köse, 2019; Bozkurt Yükçü, izoğlu Tok ve Bencik Kangal, 2019). Çocukların erken okuryazarlık becerilerini desteklemede teknoloji kullanımının olumlu etkilerini ele alan çalışmaların artmasıyla ebeveynlerin teknoloji kaygıları azalabileceği yorumu yapılabilir. Ailelerin çocuklarla kullanacakları materyaller tercihinde sadece çocuğun teknolojik araçlarla ilgilenme süresine göre anlamlı fark bulunmuştur. Teknolojiyle iki saatten fazla ilgilenen çocukların aileleri, daha az ilgilenen çocukların ailelerine göre teknolojik araçları kullanmayı daha çok tercih etmiştir. Bu sonuç, hem ailelerin çocuğun ilgisine yönelik materyal kullanmayı tercih etmeleri hem de aileler zaten teknoloji kullanımını tercih ettikleri için çocukların bu araçlarla daha çok vakit geçirmeleri gibi iki farklı şekilde yorumlanabilir. Materyal tercihinde sosyoekonomik katmana göre fark olmaması ise dikkat çekmektedir. "Evde kendim yapabileceğim ve farklı amaçlarla kullanılabilecek kostüm, maske ve oyuncaklar" maddesinin özellikle alt katmanda yer alan aileler tarafından daha fazla tercih edilebileceği düşünülmesine rağmen çalışmada böyle bir sonuç çıkmamış aksine istatistiksel olarak anlamlı olmamakla beraber bu materyal çeşidi orta ve üst katmanda daha çok tercih edilmiştir. Bu durum, orta ve üst katmandaki ailelerin, evde yapacakları materyalleri, çocuklarıyla kaliteli zaman geçirmek için bir fırsat olarak gördükleri şeklinde yorumlanabilir.

Ailelerin büyük bir kısmı dil destek çalışmaları kapsamında çocuklarıyla yapacakları etkinliklere haftada 1-2 gün ayırabileceklerini belirtmiştir. Başka bir anlatımla ailelerin büyük bir kısmı, çocuklarının erken okuryazarlık becerilerini destekleme konusunda yeni şeyler öğrenmeye ve bunun için zaman ayırmaya istekli görünmektedir. Ailelerin bu çalışmalar kapsamında evde yapacağı etkinlikler için ayırabilecekleri zaman, çocuğun sahip olduğu kardeş sayısı ile ilişkilidir. Bu sonuç beklendik olmakla beraber tüm kardeşlerin birlikte gerçekleştirebileceği etkinlikler planlanırsa programların sürdürülebilirliğinin de artacağı söylenebilir. Babanın eğitim durumunun da çalışmalara zaman ayırmada önemli bir etken olduğu görülmüştür. Bu sonuç, eğitim bakımından üst gruplarda yer alan ailelerin evde çocuklarıyla yapacakları etkinliklere daha çok zaman ayırabileceklerini göstermektedir. Son olarak, çocukla evde yapılacak çalışmaların genellikle anne rehberliğinde gerçekleştiği göz önüne alındığında çalışan ve çalışmayan anneler arasında bir fark olmaması da dikkat çekmektedir.

Aileler dil destek çalışmalarına en çok aynı evde yaşadıkları kişilerin katılmasını istemektedir. Demografik özellikler fark etmeksizin çalışmalara aile dışından gelen katılımcıları programlarda isteyen aileler azınlıktadır. Aile ile diğer kurumlar arası ilişkilerin de çocuğun gelişiminde etkili olduğu düşünüldüğünde (Bronfenbrenner, 1979) ebeveynlerin, dil destek çalışmalarında aile dışı faktörleri dışarıda tutmaya önem verdikleri görülmektedir. Bu bulgulara dayalı olarak ailelerin homojen gruplarda çalışmalara katılmayı daha çok tercih ettikleri sonucuna varılabilir. Erken okuryazarlığa yönelik aile temelli programlarda grup dinamiklerinin dikkate alınması ve diğer aile üyelerini de dâhil edecek planlamalar yapılması ailelerin katılımını ve kazanımlarının sürekliliğini arttıracaktır.

Çocuğa rehberlik edebilecek kişi büyük bir oranla anne olurken ailelerin az bir kısmı tüm hane halkının çocuklarıyla etkinlikleri gerçekleştirmesini tercih etmiştir. Alanyazında çocuklara babaları tarafından sunulan erken okuryazarlık deneyimlerinin sınırlı olduğunu gösteren araştırmalar 
bulunmaktadır (akt. Hill ve Diamond, 2013). Altıparmak'ın (2010) tez çalışmasında da annelerin çocuklarının erken okuryazarlık becerilerini destekleyici çalışmalara babalardan daha çok zaman ayırdığı ve rutin uygulamaların çocuklarının becerilerine desteklemedeki önemini daha iyi kavradıkları sonucuna ulaşılmıştır. Çocuklarla yapılacak etkinliklerde esas katılımcının baba olduğu sınırlı sayıda çalışma ebeveynlerin çalışmalara birlikte katılım göstermesinin çocuğa daha çok yarar sağlayacağına işaret etmektedir (Baker, 2013). Başka bir anlatımla, dil destek çalışmaları kapsamında her ne kadar temel rehberin anne olacağını öngören aileler fazla da olsa diğer aile üyelerinin de aktif katılımlarının sağlandığı araştırmalara ihtiyaç olduğu görülmektedir. Erken okuryazarlık becerilerine yönelik dil çalışmaları kapsamında çocuklara evde rehberlik edebilecek olan kişi tercihlerinde, bazı demografik özelliklere göre fark olmakla beraber her zaman ilk sırada anne yer almıştır. Anne tercih oranında anne mesleğine göre fark görülmüş, sadece anneyi en çok ev hanımları tercih etmiştir. Ev hanımlarındaki bu oran beklendik olmasına rağmen profesyonellik gerektiren işlerde çalışan annelerin olduğu ailelerde de çocukla en çok zaman geçirme görevinin annede olması dikkat çekmektedir. Anne rehberliğini tercih oranlarında sosyoekonomik katmana göre fark bulunmuştur. Çocuğa evde rehberlik edebilecek kişi olarak anneyi en az tercih oranı orta katmanda, en çok ise alt katmandaki ailelerdedir. Sosyoekonomik katmana göre tercihler genelde doğrusal bir sıra izlerken çocuğa rehberlik edebilecek kişi tercihinde orta katman öne çıkmışır. Bu sonuç, orta sosyoekonomik katmandaki ailelerde, çocukla ilgili tüm aile bireylerinin sorumluluk aldığına işaret edebilir. Özbek Ayaz (2015) tarafından yapılan çalışmada da alt sosyoekonomik katmandaki ailelerde çocuğa en çok kitap okuyan kişinin anne olduğu, üst sosyoekonomik katmanda ev halkının da dâhil olmakla beraber en çok okumanın anne ve baba tarafından yapıldığı görülmüştür. Elde edilen bu sonuçlar bir araya getirildiğinde; çocukla birlikte yapılacak erken okuryazarlık becerilerini destekleyici çalışmalarda asıl rehberin anne olarak görüldüğü ve bu durumun annelerin demografik özelliklerine göre değişmediği anlaşıımaktadır.

Ailelerin katılabilecekleri erken okuryazarlık destek çalışmalarında sorumluluk almalarını en çok engelleyen durum yeterli zamanlarının ya da enerjilerinin olmamasıdır. Bunu, engeli olmadığını belirten ailelerin takip etmesi, ailelerin konunun öneminin farkında olduğu ve çalışmalara zaman ayırmak için çaba harcayacakları şeklinde yorumlanabilir. Aileler, mesai saatleri dışında yapabilecekleri çalışmalara olumlu bakmaktadır. Başka bir anlatımla, ailelerin esnek zamanlarda yapabilecekleri çalışmalar planlanması programların sürdürülebilirliği açısından önemlidir. Katılacakları erken okuryazarlık becerilerini destekleyici eğitsel çalışmalarda aileleri engelleyen durumlar demografik özelliklere göre incelendiğinde, orta ve üst sosyoekonomik katmanda yer alan ya da annelerin çalıştığı ailelerde zaman/enerji yetersizliği öne çıkmaktadır. Alt sosyoekonomik katmanda yer alan ya da annelerin ev hanımı olduğu ailelerde ise engelleyici durumlar daha heterojendir. Ev içinde başka sorumluluklar, eğitim yetersizliği ve maddi imkânsızlıklar gibi ailelerin katılımını sınırlayacak faktörler belirtilmiştir. Maddi imkânsızlıklar, çocukların dil ve erken okuryazarlık becerilerini desteklemek için kullanılan en yaygın materyaller olan çocuk kitaplarına ailelerin erişimini sınırlamaktadır. Kütüphaneler ise kitaba erişimde çocuklar arasındaki fırsat eşitliği sağlanmasında önemli bir rol oynamaktadır (Celano ve Neuman, 2001). Bu nedenle özellikle alt sosyoekonomik katmanlardaki ailelerin yaşadığı bölgelere yakın çocuk kütüphaneleri kurulması, okul kütüphanelerine okul öncesi çocuk kitapları alınması ve ücretsiz kitap dağıtımı gibi çalışmaların yapılması önerilebilir.

Son olarak bu çalışma Eskişehir'de anaokulu ve anasınıflarına devam eden 5-6 yaşında çocukların aileleriyle sınırlandırımıştır. Erken okuryazarlığın ailede desteklenmesi konusunda farklı yerleşim alanlarında farklı yaş gruplarında çocukların ve babaların deneyimlerine ışık tutan yeni araştırmalar alanyazına katkı sağlayabilir. Bu araştırmada ailelerin tercihleri araştırmacılar tarafından hazırlanan sekiz kapalı uçlu soruyla toplanmıştır. Yeni veri toplama araçlarının geliştirilmesi ve farklı araştırma yöntemleri ile yeni bilimsel çalışmalar yapılması ailelerin tercihleri ve beklentilerinin daha iyi anlaşılmasına katkı sağlayabilir. Araştırmada erken okuryazarlığa ilişkin dil destek çalışmalarına odaklanılmakla beraber çocukların her türlü gelişimlerinin desteklenmesinde aileleri dâhil eden eğitim programların önemli olduğu bilinmektedir. Buradan hareketle diğer gelişim alanlarında ailenin katılımına ve bunun aileler için sonuçlarına odaklanan araştırmalar yapılması önerilebilir. 


\section{Kaynaklar}

Altıparmak, S. (2010). Erken çocukluk döneminde ebeveynlerin okuma-yazmaya hazırlık konusundaki görüşleri. Yayımlanmamış Doktora Tezi. Ankara: Orta Doğu Teknik Üniversitesi, Eğitim Bilimleri Enstitüsü.

Aram, D., Fine, Y., \& Ziv, M. (2013). Enhancing parent-child shared book reading interactions: Promoting references to the book's plot and socio-cognitive themes. Early Childhood Research Quarterly, 28, 111-122.

Arıcı, M., \& Tüfekci Akcan, A. (2019). Okul öncesi dönemde anne-çocuk birlikte hikâye kitabı okuma davranışlarının incelenmesi. Yaşadıkça Eğitim, 33(1), 100-120.

Avcı, M. (2013). Yoksulluğun dili ya da alt sosyal sınıf çocuklarının dil kodlarının eğitim sürecine etkileri. International Journal of Human Sciences, 10(1), 1050-1077.

Baker, C. E. (2013). Fathers' and mothers' home literacy involvement and children's cognitive and social emotional development: Implications for family literacy programs. Applied Developmental Science, 17(4), 184-197. doi:10.1080/10888691.2013.836034

Barratt-Pugh, C., \& Rohl, M. (2016). Evaluation of family literacy programs: A case study of better beginnings, a library-initiated family literacy bookgifting program in Western Australia. Library Trends, 65(1), 19-40.

Bee, H., \& Boyd, D. (2009). Çocuk Gelişim Psikolojisi. İstanbul: kaknüs yayınları.

Bennett, K. K., Weigel, D. J., \& Martin, S. S. (2002). Children's acquisition of early literacy skills: examining family contributions. Early Childhood Research Quarterly, 17, 295-317.

Bennett, S. V., Gunn, A. A., Gayle-Evans, G., Barrera IV, E. S., \& Leung, C. B. (2018). Culturally responsive literacy practices in an early childhood community. Early Childhood Educ J, 46, 241-248.

Boeglin-Quintana, B., \& Donovan, L. (2013). Storytime using iPods: Using technology to reach all learners. TechTrends, 57(6), 49-56.

Bozkurt Yükçü, Ş., İzoğlu Tok, A., \& Bencik Kangal, S. (2019). Çocuk edebiyatının geldiği son nokta: Okul öncesi dönem resimli e-kitaplara gelişimsel bir bakış. Erken Çocukluk Çalışmaları Dergisi , 3(1), 139-164.

Bringula, R., Rodrigo, M. M., Ocumpaugh, J. L., Porayska-Pomsta, K., Olatunji, I., \& Luckin, R. (2018). Towards the development of a computer-based game for phonemic awareness. J. C. Yang içinde, Proceedings of the 26th International Conference on Computers in Education (s. 657662). Philippines: Asia-Pacific Society for Computers in Education.

Bronfenbrenner, U. (1979). Ecology of human development. Cambridge, MA: Harvard University Press.

Carpentieri, J., Fairfax-Cholmeley, K., Lister, J., \& Vorhaus, J. (2011). Family literacy in Europe:Using parental support initiatives to enhance early literacy development (EAC/16/2009). London: NRDC, Institute of Education.

Celano, D. ve Neuman, S. B. (2001). The Role of Public Libraries in Children's Literacy Development. Pennsylvania: Pennsylvania Library Association.

Creswell, J. W. (2016). Araştırma Deseni Nitel, Nicel ve Karma Yöntemler. Ankara: Eğiten Kitap.

Doyle, A. (2012). Family literacy programs: Where have they come from and where are they going? Front. Educ. China, 7(1), 85-102. doi:10.3868/s110-001-012-0005-9

Doyle, A., \& Zhang, J. (2011). Participation structure impacts on parent engagement in family literacy programs. Early Childhood Educ J, 39, 223-233. doi:10.1007/s10643-011-0465-x

Ergül, C., Dolunay Sarıca, A., Akoğlu, G., \& Karaman, G. (2017). The home literacy environments of Turkish kindergarteners: Does SES make a difference? International Journal of Instruction, 10(1), 1308-1470.

Hershman, A., Nazare, J., Sysoev, I., Fratamico, L., Buitrago, J., Soltangheis, M., . . Roy, D. (2018). Family learning coach: Engaging families in children's early literacy learning with computersupported tools. J. C. Yang içinde, Proceedings of the 26th International Conference on Computers in Education (s. 637-646). Philippines: Asia-Pacific Society for Computers in Education . 
Hill, S., \& Diamond, A. (2013). Family literacy in response to local contexts. Australian Journal of Language and Literacy, 36(1), 48-56.

Işıkoğlu Erdoğan, N. (2016). Erken çocukluk döneminde çocuk-ebeveyn birlikte okuma etkinliklerinin incelenmesi. Kastamonu Eğitim Dergisi, 24(3), 1071-1086.

Kınık, B., Okyay, Ö., \& Aydoğan, Y. (2016). 24-36 aylık çocuklarda aile katılımlı çevre eğitiminin dil gelişimine etkisinin incelenmesi. Kastamonu Eğitim Dergisi , 24(5), 2143-2156.

Kızıltaş, E. (2009). Okul öncesi eğitimde uygulanan aile katılım çalışmalarııı 5 - 6 yaş grubu çocukların dil becerilerinin gelişimine etkisi. Yayımlanmamış Yüksek Lisans Tezi. Erzurum: Atatürk Üniversitesi, Eğitim Bilimleri Enstitüsü.

Knowles, M. S. (1984). The adult learner: A neglected species (3rd Ed.) Houston, TX: Gulf Publishing.

Korat, O., \& Shneor, D. (2019). Can e-book support low SES parental mediation to enrich children's vocabulary? First Language, 1-22.

Krejcie, R. V., \& Morgan, D. W. (1970). Determining sample size for research activities. Educational and Psychological Measurement, 30, 607-610.

Krijnen, E., Van Steensel, R., Meeuwisse, M., Jongerling, J., \& Sabine, S. (2019). Exploring a refined model of home literacy activities and associations with children's emergent literacy skills. Reading and Writing. doi:10.1007/s11145-019-09957-4

la Rie, S., Van Steensel, R. C., \& Van Gelderen, A. J. (2017). Implementation quality of family literacy programmes: a review of literature. Review of Education, 5(1), 91-118. doi:10.1002/rev3.3081

Muslugüme, E. (2016). Dil gelişimini destekleyici ebeveyn eğitim programının sosyo ekonomik düzeyi düşük ailelerin çocuklarııın dil gelişimine etkisi. Yayımlanmamış Yüksek Lisans Tezi. Denizli: Pamukkale Üniversitesi, Eğitim Bilimleri Enstitüsü.

Neuman, W. L. (2006). Toplumsal araştırma yöntemleri. Ankara: Yayın Odası.

Niklas, F., Cohrssen, C., \& Tayler, C. (2016). Parents supporting learning: a non-intensive intervention supporting literacy and numeracy in the home learning environment. International Journal of Early Years Education, 24(2), 121-142. doi:10.1080/09669760.2016.1155147

Özbek Ayaz, C. (2015). Ailelerin okul öncesi dönemdeki çocuklarının okuryazarlık becerilerini desteklemek için kullandıkları okuryazarlık uygulamalarının incelenmesi: Tekirdağ ili örneği. Yayımlanmamış Yüksek Lisans Tezi. Çanakkale: Çanakkale Onsekiz Mart Üniversitesi, Eğitim Bilimleri Enstitüsü.

Özen Altınkaynak, Ş. (2019). Annelerin okuma yazmaya hazırlık sürecine ilişkin görüşleri. Erken Çocukluk Çalışmaları Dergisi, 3(1), 98-116.

Pila, S., Lauricella, A. R., \& Wartella, E. (2018). Using short message (SMS) and multimedia messaging (MMS) to encourage positive parent-child engagement around literacy and language development. Mobile Media \& Communication, 1-21.

Samiei, S., Bush, A. J., Sell, M., \& Imig, D. (2016). Examining the association between the Imagination Library early childhood literacy program and kindergarten readiness. Reading Psychology, 37(4), 601-626. doi:10.1080/02702711.2015.1072610

Saracho, O. N. (2017). Literacy in the twenty-first century: children, families and policy. Early Child Development and Care, 187(3-4), 630-643. doi:10.1080/03004430.2016.1261513

Shamir, A., Korat, O., \& Barbi, N. (2008). The effects of CD-ROM storybook reading on low SES kindergarteners' emergent literacy as a function of learning context. Computers \& Education, 51, 354-367.

Siew, L. C., \& Tang, H. N. (2018). Using apps based medium to reach out to children with learning needs. Journal of Social Science and Humanities, 1(2), 53-57.

Teale, W. H., \& Sulzby, E. (1986). Emergent literacy as a perspective for examining how young children become writers and readers. W. H. Teale, \& E. Sulzby (Ed.) içinde, Emergent literacy: Writing and reading (s. vii-xxv). Norwood, NJ: Ablex.

Türe Köse, H. B. (2019). Okul öncesi dönem çocuklarında dijital hikaye anlatımının dinleme becerilerine etkisi. Yayımlanmamış Yüksek Lisans Tezi, Kütahya: Kütahya Dumlupınar Üniversitesi, Eğitim Bilimleri Enstitüsü. 
Van Steensel, R., McElvany, N., Kurvers, J., \& Herppich, S. (2011). How effective are family literacy programs? Results of a meta-analysie. Review of Educational Research, 81(1), 69-96. doi:10.3102/0034654310388819

\section{Introduction}

\section{Extended Abstract}

The interactions between the school and family environments are essential for the development of children during preschool years. As part of developmental processes, the early literacy skills are also byproducts of these interactions, as well as the stimuli and the interactive richness of the family environment. In order to support the development of early literacy skills gained at schools, children need literacy-rich experiences and supportive parents at home. As various researchers note, early literacy skills begin to develop at birth and natural language experiences nurture their development within the family. Therefore, families need to participate in family literacy programs to better support their children's literacy skills at home. For the highest gains, however, families should be included in family literacy programs' planning processes. Although many studies are examining family-based early literacy programs in Turkey, families' opinions are usually asked after implementing the programs. In this sense, there appears to be a lack of family voice in designing these programs. To ensure sustainability in families' literacy practices and support children's early literacy skills at home, family literacy programs should consult with parents and actively involve their voice in the planning processes. In this context, examining "what" families want to do in family literacy programs to support their children's language skills and "how" parents can involve in these programs would be valuable contribution to the literature. This study aims to describe families' preferences for language support programs about early literacy skills.

\section{Method}

As part of a larger descriptive research project conducted with a quantitative research design using the survey method, this study focuses on families' preferences on language support programs. Language support studies are known as family literacy programs in the international literature. Since the concept of family literacy is not very common in the national literature, this study uses the terms language support and family literacy programs interchangeably.

The study population consists of 2496 parents, having 5-6 years old children attending private and public preschools and kindergartens in the Tepebaşı district of Eskisehir, Turkey. The study group included 640 parents. The "Parents' Views on Language Skills in Preschool Period" questionnaire consisting of four sections was used in the original master's thesis research. This article reports the findings obtained from the third section of the questionnaire, focusing on family preferences for language support activities (8 questions) and the demographic characteristics (12 questions). The researchers prepared questions about family preferences and demographic characteristics in light of family-literacy literature. Expert opinions were obtained for the questions developed by the researchers, and pilot applications were carried out before the data collection in the research.

The data collection phase took place in the 2018-2019 Fall Semester for seven weeks, after obtaining the necessary permissions from the University' Ethics Review Board and the Ministry of National Education. The researcher went to the schools and delivered questionnaires to the classroom teachers to collect the data from the families. SPSS 22.0 package program was used for data analysis. The analysis used descriptive statistics including the frequencies, percentages, and chisquare test of independence to describe families' preferences and compare them according to some demographic variables. Cluster analysis was also performed to create a socioeconomic strata variable. Based on this variable, the parents' preferences in the lower, middle, and upper socioeconomic layers were compared. 


\section{Result and Discussion}

There were significant differences in families' preferences based on some demographic characteristics. The participant families mostly preferred information about being educative and engaging in their interactions with their children. Families' preferences on the topics they want to be informed did not differ statistically based on their demographic characteristics. As for the skills that families want to support their children; essential listening and speaking skills were the most preferred and learning new words and recognizing sounds were the least preferred areas. However, families in the lower socioeconomic layer appeared to be more interested in the skills related to reading and writing. Families' concerns in the lower socioeconomic layer about their children's future school success may explain this result. Families also preferred to receive written or visual materials sent homes during their involvement in these programs for further information. When the differences were analyzed based on socioeconomic status, the most frequent choices were school meetings for families in the lower socioeconomic layers and the technology-use for families in the upper socioeconomic layers. As for the kinds of materials, most families have preferred using educational toys with their children while they preferred using the technological tools the least. There was no difference in the material preferences of families across different socioeconomic layers.

The majority of the families stated that they could devote 1-2 days a week to support their children in early literacy; however, the number of siblings and the father's education level appeared to be important in families' time allocation at home. Despite these results, it is noteworthy that no difference in the time devoted to activities according to the mother's working status. There were no significant differences in families' preferences of who else would participate in the family literacy programs based on demographic characteristics. While most respondents expected the other family members to participate in these programs, the mother would guide children's early literacy activities at home. This tendency did not change based on the education level and the profession of the mother. The most common barrier preventing families from taking responsibility in family literacy activities was lack of time or energy. However, families from low socioeconomic layers and housewife-mothers had diversity in these barriers, such as financial insufficiency, lack of education, and having other responsibilities at home. Designing accessible and flexible family literacy programs can increase families' participation and involvement from different socioeconomic backgrounds.

Based on these results, it seems crucial to obtain families' opinions and consider their demographic characteristics in planning and designing language support programs. In this sense, focusing on such skills as letter recognition and interest in writing in these programs may increase families' involvement from lower socioeconomic layers due to their school readiness concerns. Although some families used the technology for themselves, it was noteworthy that they wanted to keep their children away from it. Informing families about the relevant uses and positive effects of technology to develop early literacy skills may be beneficial in family literacy programs. Even if many families anticipate that the mothers would be engaging in children's activities, it seems essential to ensure other family members' active participation, too. Establishing children's libraries in different neighborhoods may also benefit families from lower socioeconomic layers. As a limitation, this study focused on the parents of 5-6 years old children; therefore, future studies focusing on other age groups and fathers and using different research design approaches and measurement tools may contribute to the literature on early literacy. 